\title{
Article \\ Strategic Sustainability of Offshore Arctic Oil and Gas Projects: Definition, Principles, and Conceptual Framework
}

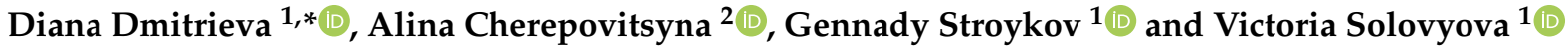 \\ 1 Department of Economics, Organization and Management, Saint-Petersburg Mining University, \\ 21St Line V.O. 2, 199106 St Petersburg, Russia; g.a.stroykov@mail.ru (G.S.); vikasolovyova9@gmail.com (V.S.) \\ 2 Luzin Institute for Economic Studies-Subdivision of the Federal Research Centre, Kola Science Centre of the \\ Russian Academy of Sciences, 184209 Apatity, Russia; iljinovaaa@mail.ru \\ * Correspondence: diana-dmitrieva@mail.ru; Tel.: +7-8921-3024-523
}

check for updates

Citation: Dmitrieva, D.;

Cherepovitsyna, A.; Stroykov, G.; Solovyova, V. Strategic Sustainability of Offshore Arctic Oil and Gas Projects: Definition, Principles, and Conceptual Framework. J. Mar. Sci. Eng. 2022, 10, 23. https://doi.org/ 10.3390/jmse10010023

Academic Editors: William

G. Ambrose and Dejan Brkić

Received: 5 November 2021

Accepted: 21 December 2021

Published: 27 December 2021

Publisher's Note: MDPI stays neutral with regard to jurisdictional claims in published maps and institutional affiliations.

Copyright: (c) 2021 by the authors Licensee MDPI, Basel, Switzerland. This article is an open access article distributed under the terms and conditions of the Creative Commons Attribution (CC BY) license (https:// creativecommons.org/licenses/by/ $4.0 /)$.

\begin{abstract}
Exploitation of oil and gas resources in the Arctic offshore is one of Russia's key priorities in such areas as science, economy, and technology. Global trends, harsh climate conditions, fragile ecosystems, conditions of the pandemic and post-pandemic periods, price volatility, and the growing importance of the environmental factor require that the process of developing the Arctic's hydrocarbon resources should become strategically sustainable. The paper provides a deep literature review on sustainability issues, sustainable development, strategic sustainability, and project efficiency in the Arctic offshore oil and gas sector. The paper analyzes the trends and conditions that substantiate the need to transform the traditional sustainability concept to meet new challenges and comply with new policies. Based on the analysis, the authors propose a definition of and a conceptual framework for strategic sustainability of oil and gas offshore projects in the Arctic.
\end{abstract}

Keywords: strategic sustainability; oil and gas offshore projects; Arctic; energy markets

\section{Introduction}

In today's global energy market, hydrocarbon resources are developed under the conditions characterized by a high degree of uncertainty. The global energy sector can be described as turbulent due to the impact of post-pandemic conditions, high price volatility, and the development of the green energy sector [1-3]. Obviously, the pandemic (COVID-19) and its consequences influenced the global energy market [4], making it more volatile and changing the trajectory of the global oil and gas sector.

According to the recent Short-Term Energy Outlook from the US Energy Information Administration (EIA), Brent crude oil prices will average USD 62.26 per barrel in 2021 and USD 60.74 per barrel in 2022 [5]. However, there is no unanimous agreement as to the future of oil prices. For example, EIA (Long-Term Brent Crude oil price projection) predicts a rapid growth in prices-to USD 120.47 per barrel [6]. Other post-pandemic forecasts are more "cautious" $[7,8]$. Figure 1 systemizes a number of current oil price forecasts provided by several global agencies. In the next few years, the most significant supply-side factors impacting pricing are expected to include US crude oil stocks, US shale oil production, and OPEC oil supply [6].

The crisis-induced slowdown in economic activity in 2020 caused the largest decline in oil demand ever-by $8.8 \%$. In the gas industry, which had been growing fast, a decline in consumption by $1.9 \%$ was recorded as well [9]. Estimates of the prospects for energy demand vary considerably. Analysts at the Organization of the Petroleum Exporting Countries (OPEC) suggest that the historical peak in oil demand is likely to come in 2035-2040 [10]. Experts at the Rystad Energy consulting company expect the growth in demand to slow down after 2028 [11]. BP assumes that oil consumption will never reach pre-pandemic levels again [12]. 


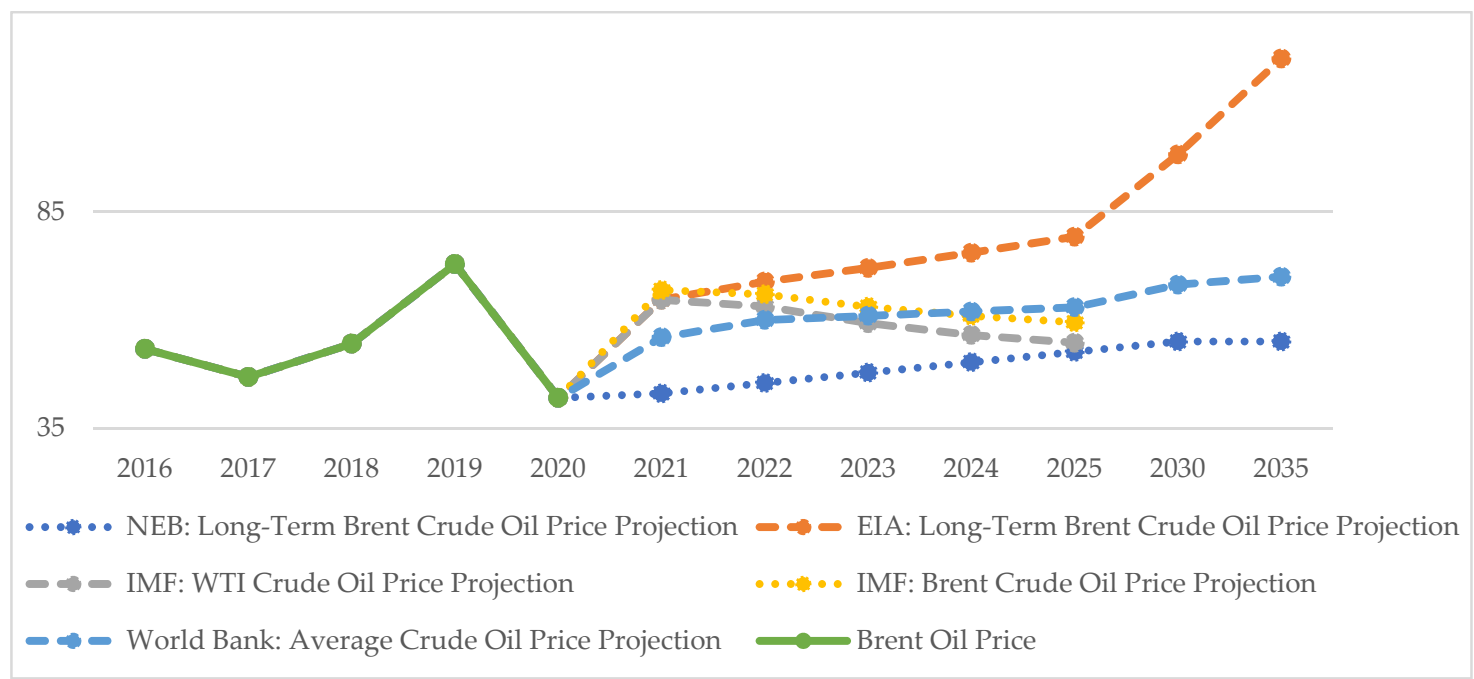

Figure 1. Brent crude price forecasts until 2035, USD per barrel. Source: made by the authors using [5-8].

The decline in the role of oil in the global energy mix is also caused by the growing importance of environmental protection and climate change issues. The development of carbon-neutral industries is fostered by a number of developed countries that intend to overcome the economic crisis by investing in environmentally friendly sectors $[13,14]$. Intensive development of the renewable energy sector is the focus of the Green New Deal. Despite the crisis, the demand for renewable energy increased by 3\% in 2020 [9]. At the same time, natural gas, being the most environmentally friendly type of fossil fuels, is a promising resource within the energy transition framework and is expected to stay competitive in the energy mix of the future. OPEC forecasts an increase in natural gas demand by $1.2 \%$ by 2045 compared to the pre-pandemic times [10].

According to the DNV GL Energy transition outlook 2020, the share of oil and coal in the primary energy supply will gradually decline [15]. In 2018, the share of oil in the global energy supply was $28.7 \%$, and coal accounted for another $26.9 \%$. The situation is expected to change dramatically by 2040 , with the share of oil projected at $20 \%$ and that of coal at only $15.5 \%$. At the same time, the volumes of solar and wind energy will increase significantly. The pie charts below show the structure of primary energy supply by source: (A) year 2018, (B) year 2040 (forecasts) (Figure 2).

Moreover, BP's Statistical Review shows that the growth in the global energy consumption was accounted for only by alternative energy sources [16]. The Skolkovo Fund predicts a $45 \%$ reduction in the global investments in the oil and gas sector [4]. The reason for this is a shift to environmental friendliness. "More and more, oil and gas companies are focusing on renewable energy and electricity storage for their own operations, biofuels as a substitute for traditional feedstock, and also on being low-carbon" (Skolkovo) [17]. BP plans to cut funding for the majority of oil and gas projects by $40 \%$.

The high turbulence of the global energy system increases the risks and uncertainty of oil and gas project implementation in Russia. Resilience of the oil and gas sector to the novel trends and tendencies (both positive and negative) determines one of the most important indicators-the national energy security. According to the current Russian policy, energy security should be based on the following principles: better energy efficiency, complying with environmental standards and requirements, reliability of power supply, etc. The fall in demand for hydrocarbons and the volatility of the pricing environment intensify competition for traditional and promising market outlets. New producers and production regions, geopolitical contradictions, the need for innovations and upgrades in the industry decrease the competitive potential of Russian oil and gas projects. Today, oil production in Russia is at the level of 2010. Over this period, oil production grew in such countries as the United States (by 113\%), Brazil (by 50\%), and Saudi Arabia (by 14\%) (Figure 3). The 
Arctic's offshore resources can be considered as an important asset that can ensure the future security of demand for Russia as the need for energy sources is expected to grow, regardless of the turbulence in the global energy market.

A)

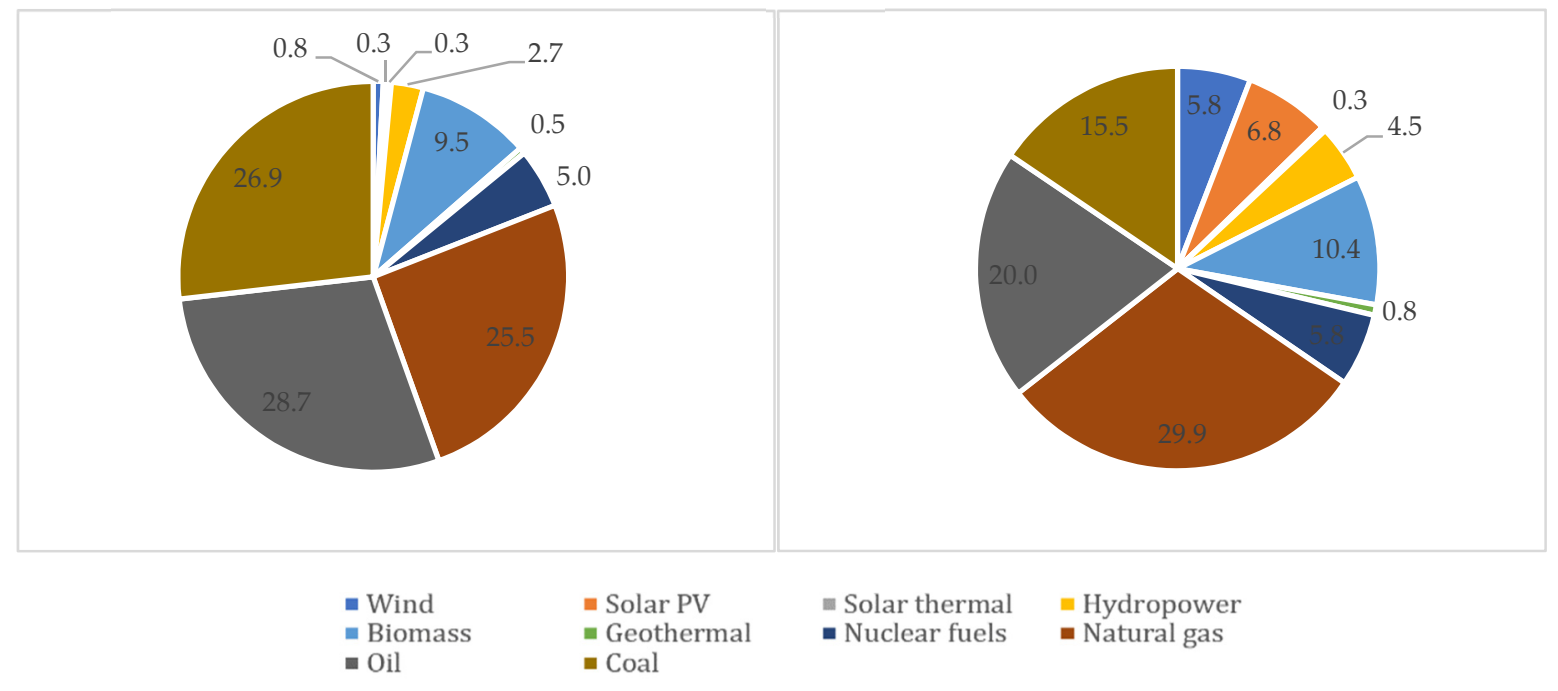

Figure 2. Primary energy supply by source: (A) in 2018, (B) in 2040, EJ/yr Source: made by the authors using [15].

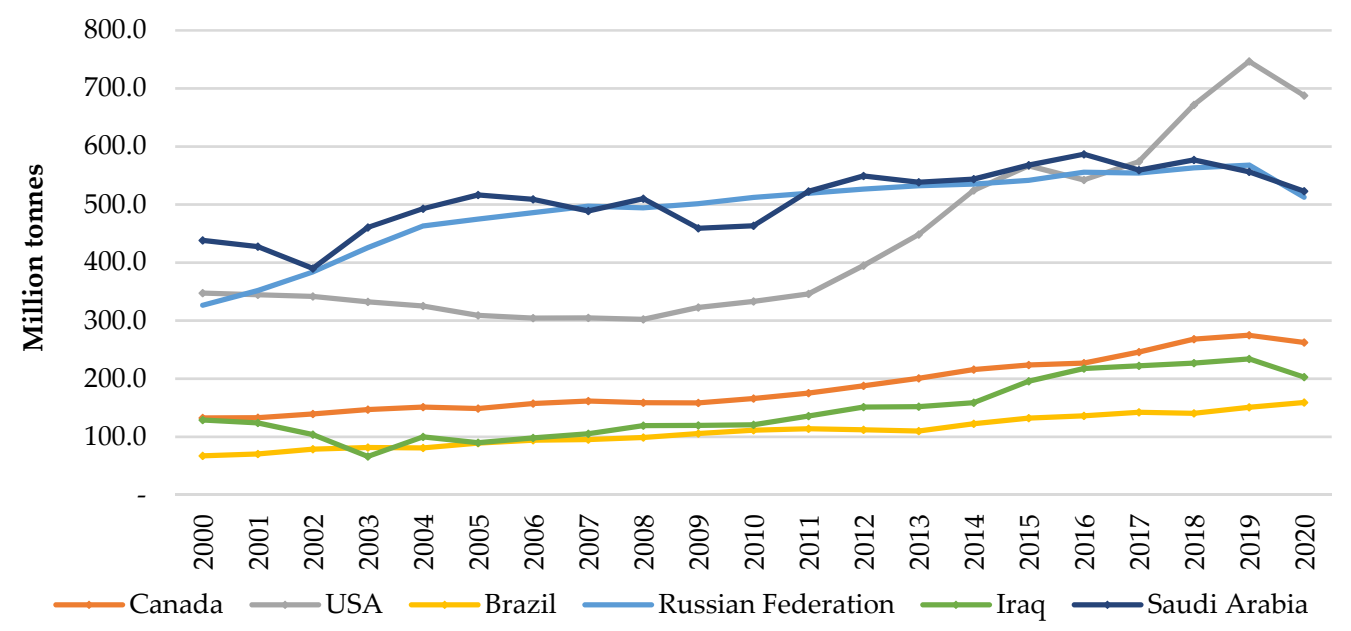

Figure 3. Oil production trends. Source: made by the authors using [12].

Nevertheless, despite the fact that the share of oil in the primary energy supply is supposed to decline, OECD predicts an increase in the global demand for oil (Figure 4).

Taking into consideration all the above mentioned and the ESG agenda, we can conclude that the long-term effective development of the Russian Arctic offshore oil and gas sector is the strategic task for the country and for the world (as gas is one of the most environmentally friendly types of fuel and Russia is one of the largest exporters of this product). According to Westwood Global Energy data, as of the end of 2020, Russia was recognized as the leader in the exploration of oil and gas fields, providing $70 \%$ of the increase in global gas reserves compared to 10-30\% in 2017-2019 [19]. This is due to several large discoveries in the Arctic, especially on its shelf. The Russian sector contains about $41 \%$ of the world's Arctic oil reserves and $70 \%$ of gas reserves [20]. The exploitation of the unique resources of minerals and fossil fuels located in the polar territories is recognized as a foundation for the social and economic development of the Arctic, stable economic growth, and the national safety of Russia [21]. Arctic oil and gas resources will play a 
key role in the country's energy mix, being a strategic reserve to replace the decline in production in traditional regions. Today, economic activity in this area provides $11 \%$ of the national income, $20 \%$ of the export [22], $17 \%$ of oil production, and $80 \%$ of natural gas production [23].

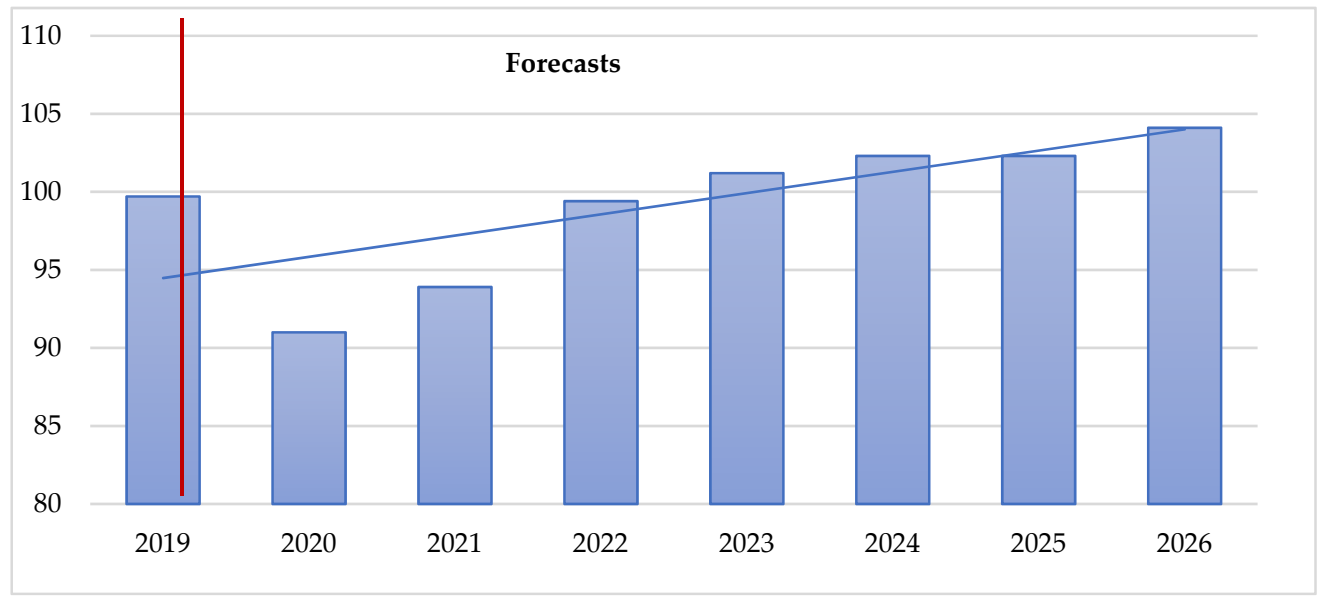

Figure 4. Global oil demand, mb/d (2018-2020_factual data, 2021-2026-forecasts). Source: made by the authors using [18].

The implementation of oil and gas projects in the offshore Arctic zone has been seen as a controversial issue by the scientific community, the government, and the public for many years [24-28]. Russia's share in the total volume of Arctic hydrocarbons is 52\% with total reserves of 510 billion tons of $n$. e. s. The development of the unique resource potential of the Arctic is of strategic importance both for ensuring Russia's geopolitical and geo-economic positions in the world, and for its internal development $[23,29,30]$. However, the large-scale shocks suffered by the global energy market that were intensified in 2020 by the COVID-19 pandemic cast doubt on the prospects for Arctic hydrocarbons [4]. The climate agenda and the fast growth of the renewable energy sector reduced the demand for traditional fuels, primarily oil [31,32]. Experts noted that these factors are particularly critical for offshore fields, which have production and technological problems and significantly low economic efficiency of investments compared to their onshore counterparts [33,34].

In these conditions, further large-scale exploitation of Arctic oil and gas resources requires an assessment of not only projects' economic indicators [35] but also their multiplicative effect on the socio-economic development of the Arctic regions [29,36,37]. In this context, the geopolitical aspect is also relevant. Russia is not the only country with an access to the Arctic territories and the interests to exploit the resource base of the North, including offshore oil and gas reserves. The USA, Norway, England, and other countries holding slices of the so-called Arctic pie develop their strategies and plans as well as technological solutions and innovations in order to use the unique hydrocarbon resources. Each of them has its own geopolitical interests and intentions which are difficult to reconcile.

Researchers widely discuss the environmental risks of oil and gas projects [38,39] and emphasize the importance of ensuring the environmental safety of oil and gas production in the Arctic $[40,41]$. An important role is assigned to the innovative and technological renewal of the Russian oil and gas industry and the digitalization of management and production processes [42-45]. The sanctions from the USA and the European countries greatly influence the national energy sector. In such a situation, it is important to overcome the sector's dependence on foreign financing and technology.

Consideration of economic efficiency in conjunction with environmental, social and technological aspects will ensure a balanced exploitation of Arctic resources based on the principles of sustainable development (SD). In view of this fact, the challenge for Arctic offshore oil and gas projects is to reach strategic sustainability. 
All of the above mentioned shapes the key goal of the research, which is to identify the concept of strategic sustainability and describe how it can be adapted to oil and gas offshore Arctic projects in a timely manner. This is possible by answering the following research questions:

RQ1: What is the nature and features of the strategic sustainability concept?

RQ2: What are the key prerequisites and principles of strategic sustainability of offshore Arctic projects?

RQ3: How can the strategic sustainability concept be adapted to offshore project implementation in the Arctic?

In order to achieve the goal and answer the RQs, we organize the paper as follows: firstly, we provide a deep literature review concerning sustainability and the SD concept and highlight the difference between the two. We then explore the strategic sustainability concept in both the global context and the context of Arctic projects. Then, we present the methodology of the research, which includes case studies, system-oriented analysis, the decomposition method, and comparative analysis, and give a detailed layout of the study. As a result, we outline the key principles, the definition, and the conceptual framework of the strategic sustainability of oil and gas offshore Arctic projects and substantiate the need to transform the traditional sustainability concept to meet new challenges.

\section{Literature Review}

To build an understanding of the theoretical and methodological aspects, we first studied the concepts of sustainability and sustainable development in order to highlight the difference between them. Then, we studied the existing approaches to the strategic sustainability concept, as well as its principles and interconnection with sustainability and SD. Additionally, we paid attention to sustainability of the Arctic offshore projects in order to create a common scientific vision of the sustainability concept applying to Arctic offshore projects. To develop the concept of project sustainability for Arctic offshore projects, we discuss and evaluate the existing practical approaches towards strategic sustainability in different spheres.

\subsection{Sustainability and Sustainable Development}

Currently, issues related to the SD concept are becoming particularly relevant within novel challenges and trends of the circular economy, the global energy transition, the principles of "green" economy, etc. [46-51]. According to the generally accepted definition, SD is a development model based on three key pillars: economic, environmental, and social $[52,53]$. To date, the concept of SD is being implemented both at the global level to meet worldwide challenges [54,55] and at the level of particular industries. As an example, a number of studies is devoted to sustainability in the mining industry as this industry has a great impact on the environment [24,56-59].

Notwithstanding the fact that the basics of SD are generally acknowledged, there are different approaches to what exactly SD means. In particular, there is no consensus in the modern scientific literature on whether the concepts of sustainability and sustainable development are synonyms or have crucially different meanings [60-63]. We present a brief outline of the points of view in Table 1.

Based on the approaches examined, we can identify three major views describing the link between sustainability and sustainable development: (1) these terms have the same meaning and are interchangeable; (2) sustainability is a general paradigm, whereas SD implies particular actions aimed at achieving it; (3) the concepts of sustainability and SD have no connection as they are fundamentally different (sustainability focuses only on environmental issues while SD focuses on achieving the SDGs). 
Table 1. Sustainability vs. sustainable development (SD)—different points of view.

\begin{tabular}{|c|c|}
\hline Sustainability vs. Sustainable Development (SD)_Points of View & Author/Source \\
\hline $\begin{array}{l}\text { Sustainability and SD are synonyms. These terms are perceived from the } \\
\text { standpoint of environmental protection, social aspects, etc. }\end{array}$ & {$[64]$} \\
\hline $\begin{array}{l}\text { The concepts of sustainability and SD are strongly related to resolving social } \\
\text { and ecological issues. Thus, they can be considered as unidirectional. A lack of } \\
\text { integrated approaches to the terms applied is explained by the pluralism of } \\
\text { opinions regarding SD issues in different sectors, companies, and projects. }\end{array}$ & {$[65,66]$} \\
\hline SD is a process to achieve sustainability goals. & {$[60,67]$} \\
\hline $\begin{array}{l}\text { Sustainability is a general paradigm of the world's future and an order based } \\
\text { on the trinity of economics, ecology, and society, while SD means concrete } \\
\text { steps for its implementation. }\end{array}$ & [68] \\
\hline $\begin{array}{l}\text { Sustainability is a key concept of how to maintain the resource potential under } \\
\text { the exhaustion of raw materials, and SD refers to particular actions. }\end{array}$ & [68-70] \\
\hline The interconnectedness of the SD and sustainability concepts. & [71] \\
\hline $\begin{array}{l}\text { Sustainability is the ability to maintain and to achieve Sustainable } \\
\text { Development Goals (SDG), and it can be both weak and strong. This idea } \\
\text { shows that "development" in the meaning of "progress" and "positive change" } \\
\text { is not applicable to all countries, companies, and projects. }\end{array}$ & {$[72,73]$} \\
\hline $\begin{array}{l}\text { The concept of SD is considered to be wider as it focuses on achieving the } \\
\text { established global SDGs, such as the development of green infrastructure, } \\
\text { formation of sustainable cities, tackling climate change, etc. }\end{array}$ & {$[74,75]$} \\
\hline
\end{tabular}

\subsection{Strategic Sustainability}

In academic literature, there is no uniform approach to defining and assessing strategic sustainability. Some authors consider strategic sustainability as an approach to "planning and implementation that allocates limited available resources with the greatest impact for sustainability" [76]. According to this opinion, the way to achieve strategic sustainability lies in comprehensive thinking about creating a plan and implementing it by identifying the main opportunities, stakeholders, and strategies needed to advance sustainability. This idea is supported further in the literature [77].

Kwon, Tang, and Kim used the concept of the strategic sustainability plan and established that developing a strategic sustainability plan provides cities with various benefits [78]. Additionally, the concept of strategic sustainability is based on strategic sustainability management (SSM) that reflects the sustainability integration process in the company's strategy $[79,80]$. SSM is analyzed in the context of the internal and external challenges of sustainability. The internal sustainability challenges include aspects of sustainability importance for the company, barriers for the sustainability implementation process, sustainability guidelines in the company's policy, etc. Internal challenges describe aspects of stakeholders' involvement in the sustainability implementation process.

The strategic sustainability concept is also viewed through the prism of the framework for strategic sustainable development (FSSD) [81,82]. The FSSD was transformed to the strategic sustainability procedures (SSP) concept [77]. While formulating this concept, the authors emphasize the difference between sustainability and SD and consider sustainability as "a vision for the socio-ecological system", while SD is described as "a tangible and actionable set of processes that occur within the operations of the business". At the same time, the authors highlight their congruence and their connection with the usual strategic management process. The authors suggest procedures that can provide strategy content for the business strategy planning process in a system focused on society and the environment.

According to Malenkov et al., strategic sustainability "is the ability of a system to recover from the external and internal impacts and changes, while stability is keeping a certain range of system parameters unchanged or allowing them to change within preset 
limits" [83]. The authors suggest a model for strategic sustainability assessment, which is based on a set of digital components that influence the company's sustainability.

As for strategic sustainability assessments, Singh et al. suggest a detailed overview of sustainability assessment methodologies, which shows that many authors suggest using various sustainability indexes in order to measure SD [84].

The above mentioned can be done by using the strategic sustainability justification methodology (SSJM) introduced by Presley et al. SSJM requires distinct identification of the company's objectives, strategies, and processes [85]. The authors suggest three levels of assessment-strategic, tactical, and operational, and provide indicators for each aspect (economic, social, and environmental).

Furthermore, some authors describe sustainability indicators for renewable energy technologies, such as electricity prices, greenhouse gas emissions, availability of renewable sources, energy conversion efficiency, land requirements, water consumption, and social impacts [86].

Another methodology for strategic sustainability assessment described in the literature is strategic sustainability analysis (SSA) [87]. It is applied in the integrated long-term assessment of policies and programs, and requires a dynamic, quantitative, and consistent algorithm. We provide approaches to strategic sustainability in Figure 5.

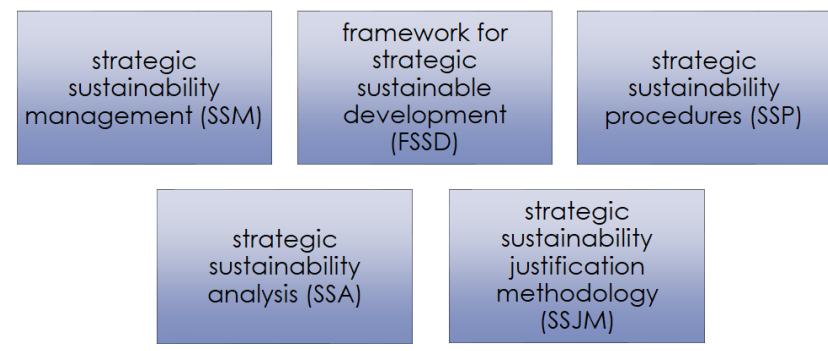

Figure 5. Approaches to strategic sustainability (compiled by the authors).

Nowadays, companies' and projects' management is faced with the necessity to strike a balance between operational effectiveness and strategic thinking on the sustainability issue [88]; in our opinion, this is the cornerstone for the achievement of strategic sustainability.

Despite a wide range of literature concerning strategic sustainability, there is no common definition or concept. Strategic sustainability in scientific literature is considered from different points of view. On the one hand, SS is considered as a strategic vision of sustainability, while on the other, it is closely connected with the sustainable development concept and it is also seen as the stability of the system itself (i.e., there is independence from the environment).

\subsection{Efficiency/Sustainability Assessment of Arctic Oil and Gas Projects}

Currently, the issues related to SD with regard to the development of Arctic territories are becoming particularly relevant. According to the Foundations of the Russian Federation State Policy in the Arctic for the Period up to 2035, one of the key strategic goals is to achieve sustainability of exploration in the Arctic [89].

The World Wildlife Fund (WWF) identifies the sustainability of Arctic oil and gas resource exploration as a key priority [90]. The reason for this is the irreversibility of the impact on the Arctic zone on a global scale. The Arctic Biodiversity Assessment report points out that resource exploration in the Arctic is a good opportunity to apply SD principles in practice [91].

Russian academic literature provides different approaches to defining sustainability in terms of developing the Arctic's resource potential. There are a number of studies which suggest that SD is closely related to the Climate Agenda, namely, to reducing climate risks, $\mathrm{CO}_{2}$ emissions, etc. [92]. Several studies attempted to assess sustainability of resource exploration in the Arctic in terms of environmental aspects, such as the rational use of 
mineral resources, ensuring a high level of energy and resource efficiency, reducing the environmental impact, and preserving fragile ecosystems [93]. Gassiy et al. concluded that the SD of the Arctic systems is determined by a balance between the interests of key stakeholders - the state, business, science, society, etc. [94]. An ambiguity in the approaches to the Arctic's SD leads to the uncertainty in the interpretation of SD when individual projects are implemented (in particular, Arctic oil and gas offshore projects).

The research "Foresight study of the development of the Arctic offshore industry until 2030" highlights factors that are contributing to the SD of the Arctic zone. They include natural resource parameters, transport trends (including infrastructure), and climate aspects [95].

Fadeev et al. discuss the sustainability of hydrocarbon projects through the prism of their potential impact on the development of the Arctic region. To assess the efficiency of these projects and to determine the level of their impact on the SD of the region, an integral indicator of the technical and economic potential of oil and gas fields is proposed. It was calculated based on technical, climate, and economic indicators [96]. The report "Challenges and opportunities of oil and gas investment in the Arctic" also considers the efficiency and investment attractiveness of offshore projects from the standpoint of their contribution to the sustainable socio-economic development of the northern region. However, there are no practical recommendations on how exactly this contribution should be assessed [97].

Recently, the interest of the global community in Arctic projects has increased despite the continuing discussions about the changing role of traditional energy resources. Stipo et al. argue that the level of sustainability of Arctic offshore projects influences environmental preservation [98]. Verhaag identifies two major driving forces of the SD of offshore resources. They include (1) ensuring the principles of the rational use of natural resources and (2) implementing a "precautionary approach" (concentration of efforts to prevent possible environmental consequences) [99]. It can be concluded that sustainability of Arctic projects in most cases is considered precisely in terms of environmental aspects [100,101].

Lee investigates the key problems of SD of the northern resource potential on the example of oil and gas projects in Alaska [102]. It is stressed out that oil and gas companies (and projects as well) have to focus on SD principles because of new global trends and tendencies. The factors influencing SD include more stringent state policies, restricting access to financial capital (a number of American banks have announced the termination of investment in Arctic projects), and the growing role of scientific and technological progress (new requirements for technological support of production processes in the exploitation of offshore fields).

At the same time, despite the relevance of the SD problem to Arctic offshore projects, there is no universal methodological approach to assessing the degree of sustainability (including strategic sustainability) taking into account the specifics of such projects and the Arctic territories as a whole. It is not clear which indicators should be used, how to calculate integral indicators for all parameters, how to compare different projects, and what this may ultimately affect.

As a rule, when analyzing the future opportunities for developing the offshore hydrocarbon potential, such an economic category as efficiency is used. In 2016, Gazprom Neft PJSC developed a special methodology for the economic assessment of offshore projects aimed at optimizing the implementation of the Prirazlomnoye field exploration and other large-scale projects planned to be implemented in the future [103]. Using this technique, it is possible to rank wells taking into consideration their efficiency based on the calculation of the allocation costs for field exploitation, as well as to carry out a comprehensive assessment of the associated environmental and geological risks. Nevertheless, social and environmental parameters are not taken into account when using this technique (it can be viewed as a disadvantage).

Gazeev et al. offer an approach to assessing the efficiency of Arctic offshore projects based on three pillars-economic, innovative (technological), and environmental [104]. 
The research does not use the term "sustainability". However, the very idea of moving away from focusing solely on financial and economic aspects corresponds to the concept of sustainability. A number of other Russian authors adhere to the same position $[105,106]$.

Currently, the Arctic Council is implementing a project aimed at creating novel approaches to apply the global SDG in practice by organizing international project meetings, providing an inter-institutional gap framework analysis, developing online decision support tools, etc. [107]. Mineev et al. presented a methodology to assess a degree of commitment to SDGs. It includes five pillars-people, society, economics, environment, and partnerships, which correspond to certain indicators. Indicators are divided into three categories: green, yellow, and red, according to a degree of commitment to SDGs [108].

In the global report titled "Sustainable Development Action-the Nordic way", the sustainability of Arctic projects and industrial systems is proposed to be assessed by conducting a comprehensive analysis of stakeholders, taking into account the level of involvement of individual groups, their target priorities, and the possibility of ensuring a balance of their interests [109].

A holistic methodology for assessing the strategic sustainability of hydrocarbon offshore projects by applying the method of hierarchical analysis was proposed in a study by Cherepovitsyn et al. Its peculiarity lies in taking into account the specifics of conditions and key parameters for the implementation of Arctic offshore projects (investment, geological, economic, environmental, and social) [24]. At the same time, this study reflects the sustainability of projects only from the perspective of their implementation [110].

After a thorough analysis of scientific literature on the topic, we come to the conclusion that there are few studies devoted to sustainability of oil and gas Arctic projects. Therefore, our study is aimed at making the following contribution to scientific literature: developing a definition of the strategic sustainability concept for Arctic offshore projects, as well as its principles and conceptual framework that could be used by researchers in this sphere or adopted to others.

\section{Methodology}

The methodology of this study includes case studies, system-oriented analysis, the decomposition method, and comparative analysis. The study is based on an extensive list of references. We conduct a literature review in the following directions (Figure 6) to ensure a comprehensive approach to the topic discussed.

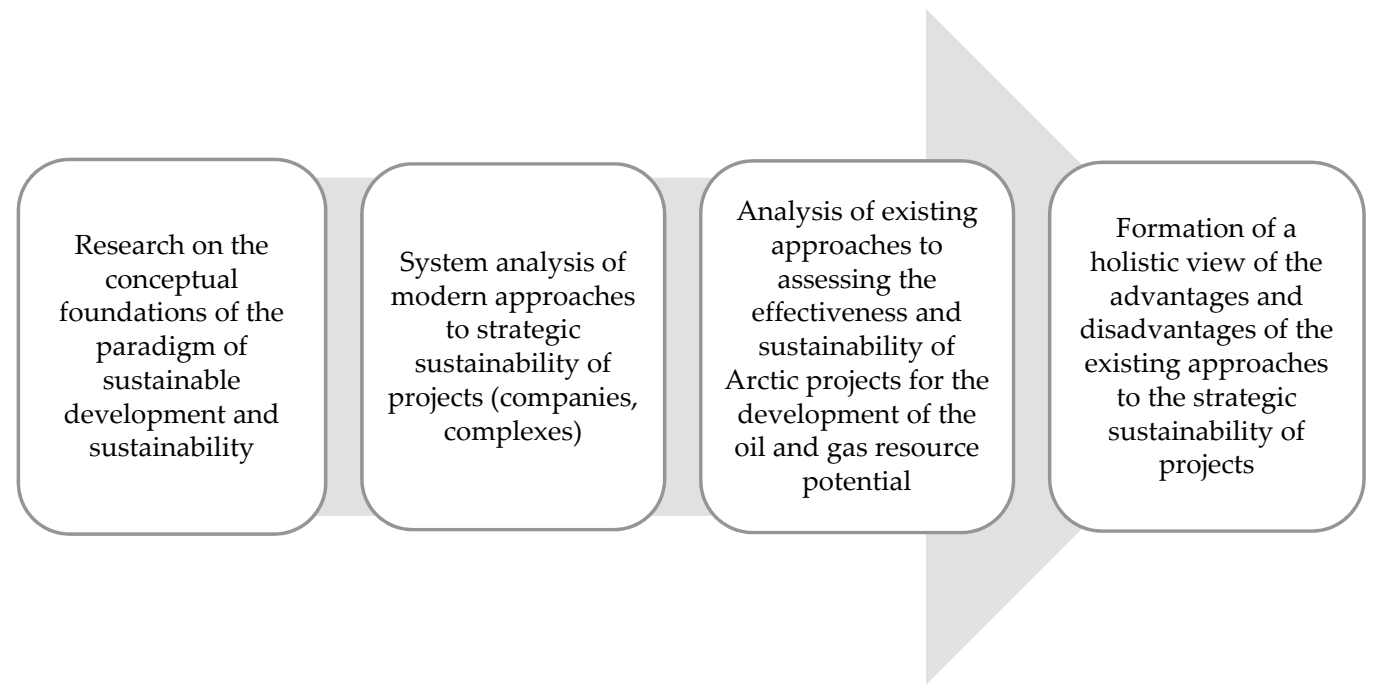

Figure 6. Theoretical basis of the research.

Economic, social, and environmental factors are important, but they are not the only variables for Arctic offshore projects to take into consideration. We argue that there is a 
research gap between the existing approaches to project sustainability and current trends (including SDG, low-carbon development, etc.). Therefore, the existing methodological frameworks should be complemented to conform to modern trends and challenges taking into consideration not only the projects' specifics and the key SD parameters, but also the turbulence of the macroeconomic environment and the current requirements to the projects from stakeholders, investors, etc.

As it was noted above, strategic sustainability is focused not on operational decisions, but on long-term ones. To create a novel concept, it is important to understand the current trends and existing prerequisites for strategic sustainability of Arctic oil and gas offshore projects (Figure 7 ).

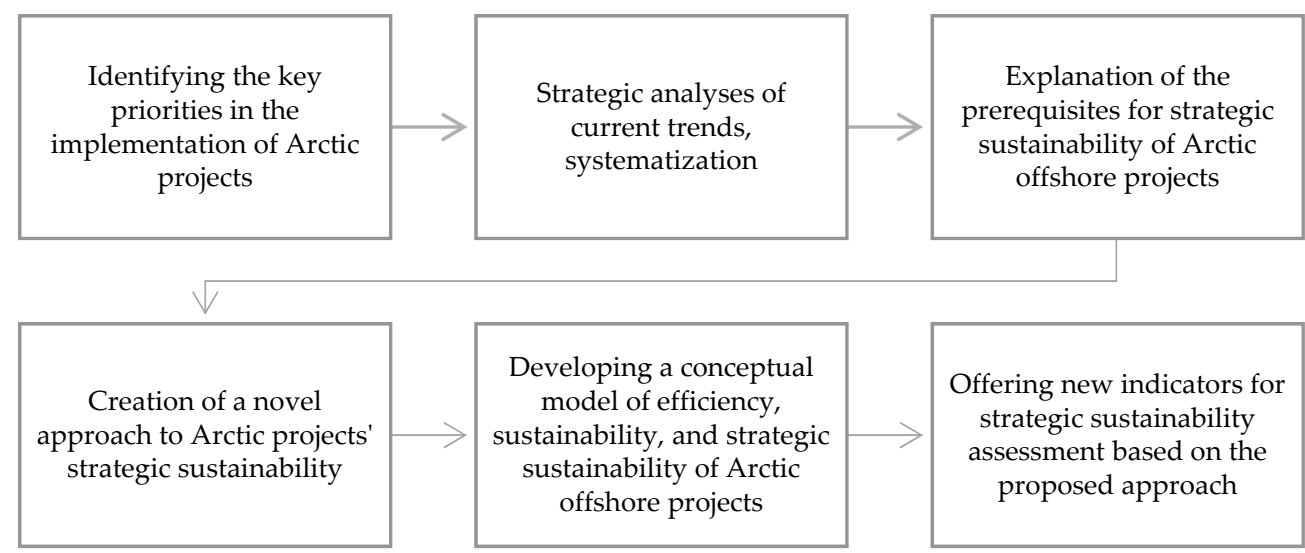

Figure 7. Strategic sustainability of Arctic offshore oil and gas projects.

To expand the vision of the tendencies on the global energy scale, we take modern concepts related to responsible and sustainable business and discuss them considering their potential influence on the future of the oil sector in general and that of hydrocarbon projects in particular.

We attempt to adopt ESG factors to oil and gas projects considering their specifics and possible contribution towards SDGs. Moreover, we try to understand how to ensure SD in the highly turbulent environment as investors' priorities are changing, the role of traditional resources is being transformed, and the concept of low-carbon development is gaining momentum. In the current conditions, Arctic oil and gas projects are sensitive not only to economic factors (price volatility, demand, etc.), but to global challenges as well. To implement them efficiently, we should follow new requirements, new standards, and the novel strategic sustainability concept.

\section{Results}

4.1. Modern Trends in the Oil and Gas Industry That Justify the Necessity of Strategic Sustainability of Arctic Offshore Oil and Gas Projects

Nowadays, economic efficiency is not the only indicator to determine if the project is attractive for investors or not. Environmental and social components are also particularly important, especially for the mining industry (as mining processes are supposed to be unsustainable by nature [111,112]). McKinsey and Company noted: "As oil and gas companies respond to the current economic discontinuities, they must choose where and how to compete as the world transitions to a low-carbon future" [113]. For example, Norway's priorities for the development of its Arctic region (according to the state policy) are closely related to the key directions of SD concepts and meet the global trends [114]:

- International cooperation (economic);

- Business development (economic);

- Knowledge development infrastructure (social);

- Environmental protection (environmental);

- Emergency preparedness (environmental). 
As it was mentioned, some modern tendencies are intensifying and they can be perceived not only as threats, but as novel opportunities. For example, the growing technological complicity and the adaptation of new intelligent technologies in resource exploitation in the Arctic require significant capital investment. On the other hand, they become key factors to achieve safety in challenging natural and climatic conditions, to automate production processes, to reduce costs, and to maintain competitive positions on the global market. Thus, global trends and tendencies are the main prerequisites for adapting the strategic sustainability concept to oil and gas projects.

Table 2 presents global trends in the energy sector in the context of strategic sustainability. We tracked the influence of each of the modern global trends on the industry as a whole and on oil and gas Arctic projects in particular.

Table 2. Global trends in the energy sector as prerequisites for the strategic sustainability of Arctic offshore oil and gas projects.

\begin{tabular}{|c|c|c|c|}
\hline Global Trends & $\begin{array}{c}\text { Description-The Case of Arctic } \\
\text { Offshore Projects }\end{array}$ & $\begin{array}{c}\text { Prerequisites for Implementing the } \\
\text { Strategic Sustainability } \\
\text { Approach }\end{array}$ & Key Aspects \\
\hline $\begin{array}{l}\text { Strengthening } \\
\text { competition in } \\
\text { traditional } \\
\text { hydrocarbon } \\
\text { markets }\end{array}$ & $\begin{array}{l}\text { The growing intensity of competition } \\
\text { leads to searching for new opportunities } \\
\text { to develop hydrocarbon resources. } \\
\text { Therefore, Arctic offshore reserves are } \\
\text { becoming important as prospective } \\
\text { sources for meeting the global demand } \\
\text { for energy resources [115]. }\end{array}$ & $\begin{array}{l}\text { A need to create novel competitive } \\
\text { advantages to achieve and to maintain } \\
\text { high positions on the global market; } \\
\text { ensuring the investment attractiveness of } \\
\text { offshore projects, taking into account } \\
\text { current requirements and approaches to } \\
\text { assess it (ESG indicators). }\end{array}$ & $\begin{array}{l}\text { Economic/ } \\
\text { Governance }\end{array}$ \\
\hline $\begin{array}{c}\text { Transition to } \\
\text { low-carbon } \\
\text { development } \\
{[2,116]}\end{array}$ & $\begin{array}{l}\text { For Arctic offshore projects, this } \\
\text { challenge is particularly relevant. In 2020, } \\
\text { multiple United States banks, including } \\
\text { Wells Fargo \& Company and Goldman } \\
\text { Sachs, announced that they would not } \\
\text { fund new offshore projects in the Arctic } \\
\text { as these projects do not follow the } \\
\text { established low-carbon directions [117]. } \\
\text { Deloitte argues that investors request the } \\
\text { long-term strategies of oil and gas } \\
\text { companies to understand if they follow } \\
\text { the climate and environment priorities or } \\
\text { not [116]. Oil and gas companies should } \\
\text { balance the investments needed to ensure } \\
\text { sufficient supplies against the necessity } \\
\text { of cutting emissions [18]. }\end{array}$ & $\begin{array}{l}\text { A need to transform current business } \\
\text { models. According to Deloitte, oil and } \\
\text { gas companies have only two options to } \\
\text { remain viable during the transition (to be } \\
\text { resilient and sustainable): } \\
\text { (1) Diversifying into other forms of } \\
\text { energy and enabling technologies (new } \\
\text { competencies in renewables, novel } \\
\text { technologies, focus on biofuels); } \\
\text { (2) Turning emissions into a business } \\
\text { opportunity (carbon capture } \\
\text { technologies). }\end{array}$ & $\begin{array}{l}\text { Ecological/ } \\
\text { Economic }\end{array}$ \\
\hline $\begin{array}{l}\text { The growing role } \\
\text { of innovation } \\
\text { (technologies) }\end{array}$ & $\begin{array}{l}\text { Arctic offshore projects require } \\
\text { innovative technologies to exploit the } \\
\text { resource base. Practice shows that there } \\
\text { is a direct correlation between } \\
\text { profitability of Arctic offshore projects } \\
\text { and the current level of technological } \\
\text { advances [118]. This fact was proven by } \\
\text { Norwegian companies-the break-even } \\
\text { rate of offshore projects reached USD } 20 \\
\text { per barrel (Johan Castberg oil field) [119]. } \\
\text { By contrast, a break-even point for } \\
\text { Russian offshore projects is about USD } \\
50-70 \text { per barrel [118,120]. }\end{array}$ & $\begin{array}{l}\text { The need to develop innovative } \\
\text { technologies and approaches, to } \\
\text { minimize the level of import dependency } \\
\text { on foreign equipment and technologies } \\
\text { for offshore resources' exploitation } \\
\text { (ice-resistant platforms, drilling rigs, etc.). } \\
\text { Overall, the level of technological } \\
\text { advances should become the key factor to } \\
\text { resist the trends of high oil price volatility } \\
\text { (maintain competitive positions on the } \\
\text { global market against onshore oil } \\
\text { projects). "Green" innovations might } \\
\text { provide a contribution to environmental } \\
\text { aspects. }\end{array}$ & $\begin{array}{l}\text { Economic/ } \\
\text { Ecological }\end{array}$ \\
\hline
\end{tabular}


Table 2. Cont.

Global Trends Offshore Projects
Prerequisites for Implementing the Strategic Sustainability Approach
Key Aspects

The need to develop and implement novel digital technologies. The effects can be discussed in different directions: social: to minimize labor; intensity, to reduce risks at work, to reduce the influence of the human factor; economic: to reduce production costs, to optimize production processes;

ecological: to ensure effective operations without environment consequences, to enhance control systems (environmental factor).
The growing role of digitalization sformation of management sys data, digital tools and management mechanisms, technologies (remote sensing platforms, intelligent and smart technologies) [121]
According to Norway's Arctic strategy, it is essential to balance opportunities and responsibility [114]. A responsible business practice implies respect for human rights and standards [122].

The term of corporate social

Social awareness responsibility (CSR) in case of the Arctic means to reconcile the priorities of key stakeholders and to have an open dialogue with the public (the Arctic Council as a platform for interaction).

Environmental aspects are of particular importance in offshore projects as the Arctic's environment is fragile and unstable. Specific risks associated with developing offshore hydrocarbon

Environmental safety resources include oil spills, pollution, etc. The consequences of incidents might be not only dangerous but also irreversible.

In severe weather conditions, it is impossible to react immediately to oil spills [123].
The need to follow the current principles of corporate social responsibility, to

integrate in the global system (the Arctic

Council), to enhance tools and methods for interacting between the state,

business, investors and society, to focus on open policy in the case of CSR.

Social/Economic/

Environmental$$
\text { che }
$$

The need to minimize or even to eliminate possible environmental risks of offshore reserve exploration by implementing special technologies for preventing environmental incidents, and improving the control system quality. According to the SD concept, environmental impact is vital to consider when making long-term investment decisions.
Ecological/ Governance

Global trends in the energy sector create important conditions for implementing the strategic sustainability approach. The analysis shows that issues related to SD correspond to the category of project investment attractiveness. Taking into consideration the complexity and capital-intensity of Arctic oil and gas offshore projects, it can be concluded that investment attractiveness is essential. However, as we can see, foreign banks, companies, and investors are changing their priorities towards responsible business and sustainable projects. The more risky the project, the more efforts should be made to reconcile the key directions-economic, social, and environment. Strategic sustainability of Arctic offshore projects needs to be viewed through the SDG concept. According to previous research, the following SDGs are involved in developing the Arctic's oil and gas potential [44]: SDG 1, SDG 3, SDG 5, SDG 6, SDG 7, SDG 8, SDG 9, SDG 10, SDG 12, SDG 11, SDG 13, SDG 14, SDG 15, SDG 16, SDG 17. The most important SDGs for offshore projects can be systemized as follows:

SDG 3. Good health and well-being.

SDG 9. Industrialization, innovation and infrastructure.

SDG 11. Sustainable cities and towns.

SDG 12. Responsible consumption and production. 
SDG 14. Conservation of marine ecosystems.

SDG 17. Partnership for sustainable development.

This concept can be applied not only to offshore oil and gas projects. The same list of SDGs, including SDG 8 (Decent work and economic growth), works for navigation projects. For alternative energy projects, such sustainable development goals as SDG 7 (Affordable and clean energy) and SDG 13 (Climate action) are particularly important.

The ESG concept is one of the important pillars as it complements the traditional SD model and reflects new requirements towards responsible investment and governmental regulation. Examples of ESG information include the environmental dimension (pollution, biodiversity loss, greenhouse gas emissions, waste management, renewable energy, energy efficiency [124]); the social dimension (quality of life, well-being, diversity, equality, employee relations, and human capital management), and the governance dimension (internal controls, regulations, board of directors, diversity, independence, information transparency, and risk management) [125-129].

ESG has been proposed as a strategic measure that allows companies to increase profits, the amount of attracted investment in company's projects, as well as an indicator of responsibility, corporate reputation, and consumer confidence [130,131]. Implementing sustainable practices helps companies gain competitive advantage over competitors in the industry, increasing productivity and intensity while reducing exposure to systematic risks.

In today's business environment, corporate governance, and financial transparency have an impact on corporate performance. These changes are important for understanding the widespread availability of relevant and reliable information related to financial and non-financial aspects of the company's operations. Environmental, social, and governance disclosure metrics have gained a reputation for playing a fundamental role in financial transparency. Research shows that environmental, social, and governance reporting is a means for a company to communicate with its stakeholders as part of its accountability and governance obligations, and at the same time, it is a tool for achieving transparency regarding the company's financial performance [127-129,132-134].

\subsection{A Conceptual Framework for Strategic Sustainability in Arctic Oil and Gas Projects}

Arctic offshore projects are known for their large scale. Thus, all the decisions made can be irreversible for the environment, local communities, etc. It is impossible to simply stop project implementation without any consequences. Therefore, all the steps should be thought out, and all the aspects (including environmental and social) should be taken into consideration. Moreover, as it was noted above, opportunities and responsibility have to be in balance.

Based on the tendencies and novel requirements discussed, we systemize the key principles of strategic sustainability regarding Arctic offshore projects. They include adaptability, taking into consideration stakeholders' interests, commitment to the global SDGs, etc. (Figure 8).

All the above mentioned substantiates the need to transform the traditional approach to sustainability (Figure 9). The projects' strategic sustainability is a way to implement investment projects in accordance with the key principles of the SD concept based on the adaptation to the current challenges and the novel opportunities through strengthening competitive advantages, transforming traditional approaches toward sustainability, and following technological advances. Strategic sustainability of Arctic oil and gas projects is primarily a complex dynamic system due to resource constraints and contradictions between the interests of various stakeholders. The priority objective in this case is not to ensure stable development but to be adoptive to a highly turbulent macroeconomic environment. 


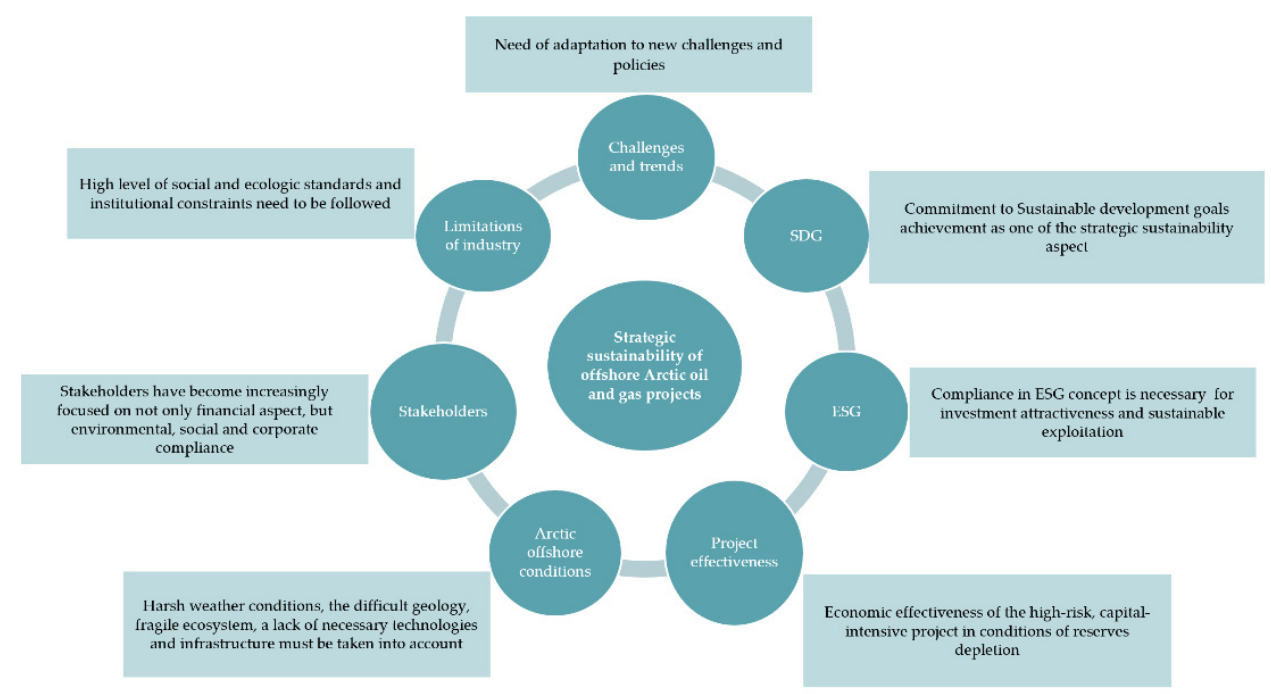

Figure 8. Principles of strategic sustainability regarding Arctic offshore projects.

\begin{tabular}{|c|c|c|c|c|c|}
\hline \multicolumn{3}{|c|}{ Traditional approach to Project Sustainability } & \multicolumn{3}{|c|}{$\begin{array}{c}\text { Novel approach to Project Sustainability - Strategic } \\
\text { Sustainability }\end{array}$} \\
\hline \multicolumn{6}{|c|}{ Essence } \\
\hline $\begin{array}{l}\text { Stability in a chang } \\
\text { of planned i }\end{array}$ & $\begin{array}{l}\text { xternal and internal er } \\
\text { tors (primarily financ }\end{array}$ & $\begin{array}{l}\text { nment, achievement } \\
\text { nd economic) }\end{array}$ & \multicolumn{3}{|c|}{$\begin{array}{l}\text { Integrating the SD principles, adaptability to emerging challenges } \\
\text { and new opportunities by building up novel competitive } \\
\text { advantages, changing approaches to strategic management, } \\
\text { following the pace of scientific and technological progress }\end{array}$} \\
\hline \multicolumn{6}{|c|}{ Key directions } \\
\hline $\begin{array}{l}\text { Planning is a key } \\
\text { function }\end{array}$ & $\begin{array}{c}\text { Focus on an excess } \\
\text { of income over } \\
\text { expenditure }\end{array}$ & $\begin{array}{l}\text { Stability is a key } \\
\text { factor (minimizing } \\
\text { the losses, risk } \\
\text { avoidance) }\end{array}$ & $\begin{array}{l}\text { Designing a system } \\
\text { of flexible indicators } \\
\text { to assess } \\
\text { environmental, } \\
\text { social, and economic } \\
\text { variables }\end{array}$ & $\begin{array}{l}\text { Integration of the SD } \\
\text { goals and ESG- } \\
\text { factors into the } \\
\text { strategic } \\
\text { management system }\end{array}$ & $\begin{array}{c}\text { Correlation between } \\
\text { project investment } \\
\text { attractiveness and } \\
\text { degree of } \\
\text { responsibility and } \\
\text { commitment on SD } \\
\text { principles }\end{array}$ \\
\hline \multicolumn{6}{|c|}{$\sqrt{5}$} \\
\hline \multicolumn{3}{|c|}{$\begin{array}{l}\text { Local nature of the effects achieved, the } \\
\text { main criterion - financial stability }\end{array}$} & \multicolumn{3}{|c|}{$\begin{array}{l}\text { Achieving multiplier effects, the main } \\
\text { criterion - adherence to the SD } \\
\text { goals(responsible business) and } \\
\text { adaptability to the conditions of a } \\
\text { turbulent macroenvironment }\end{array}$} \\
\hline
\end{tabular}

Figure 9. Transformation of the sustainability concept.

Thus, according to the concept offered, the strategic sustainability concept includes both the efficiency and the sustainability of investment projects. It covers not only economic aspects (economic and financial efficiency-microeconomic level), but also social and environmental pillars (SD foundation-macroeconomic level) and novel findings provided in this research-"Sensitivity to trends and volatility + Contribution to the achievement of the SDGs + Commitment to ESG factors". Figure 10 presents the conceptual approach we created to show the understating of the strategic sustainability concepts.

According to this novel approach towards strategic sustainability, the economic efficiency, social, and ecological pillars are important, but not enough to assess projects' positions. Table 3 presents the key indicators for assessing the efficiency, sustainability, and strategic sustainability of Arctic offshore projects. As it was mentioned before and shown in Figure 10, the strategic sustainability concept includes efficiency, sustainability, and extra factors such as sensitivity to trends and volatility, contribution to the achievement of the SDGs, and commitment to ESG factors. 


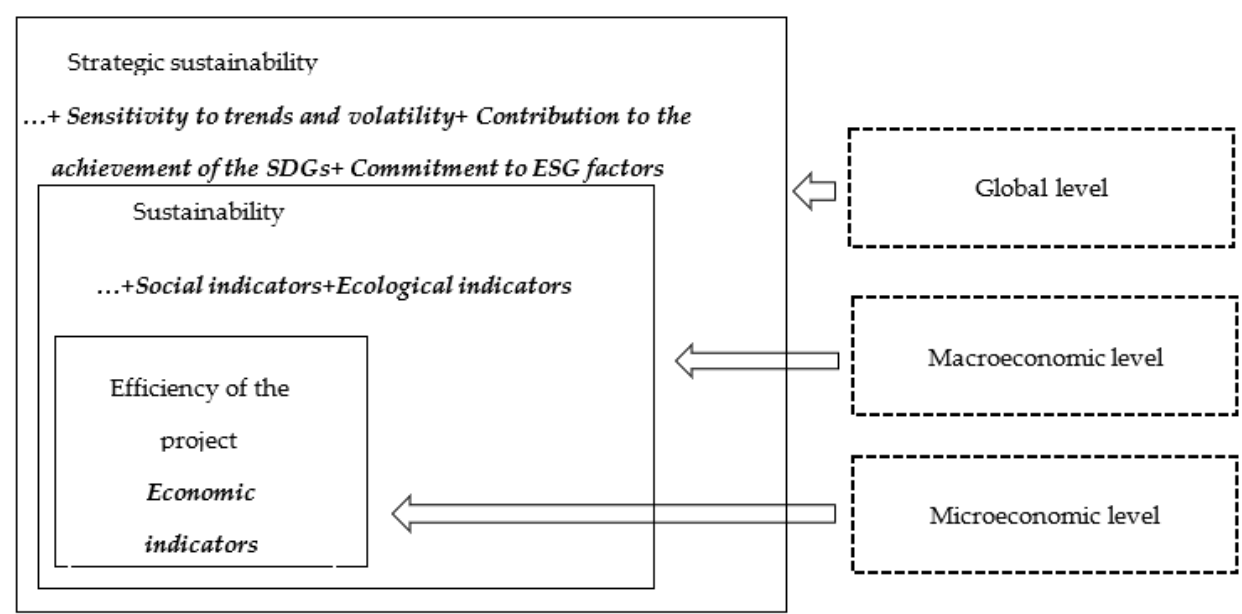

Figure 10. Conceptual framework for the strategic sustainability of Arctic offshore projects.

To determine the level of sensitivity of oil and gas projects towards new trends and volatility, we offer to apply an expert method. The tendencies discussed are different and multidirectional. Therefore, it is complicated to formalize them (see Appendix A).

Thus, the key findings of the research are the following:

- the unpredictability of the oil and gas market caused by high price volatility, postpandemic consequences, as well as green energy trends, substantiates the need for a special approach to the exploitation of Arctic offshore resources;

- implementation of Arctic offshore projects nowadays requires not only economic justification, but also considering environmental, social, and governance aspects, which becomes possible if the strategic sustainability approach is used;

- $\quad$ the strategic sustainability approach in the case of Arctic offshore projects is a complex dynamic system that allows for implementing such projects in accordance with the key principles of the SD concept based on the adaptation to the current challenges and the novel opportunities through strengthening competitive advantages, transforming traditional approaches towards sustainability, and taking into consideration resource constraints and contradictions between the interests of various stakeholders;

- the strategic sustainability concept covers not only economics aspects (economic and financial efficiency-microeconomic level), but also social and environmental pillars (SD foundation-macroeconomic level) and novel findings provided in this research"Sensitivity to trends and volatility + Contribution to the achievement of the SDGs + Commitment to ESG factors".

Table 3. Key indicators for assessing the strategic sustainability of Arctic offshore projects.

\begin{tabular}{|c|c|c|}
\hline & proach & Indicators \\
\hline \multirow{8}{*}{ Efficiency } & \multirow{8}{*}{$\begin{array}{l}\text { Economic indicators } \\
\qquad[24]\end{array}$} & $\begin{array}{l}\text { Investments (including geological surveying costs, construction of infrastructure } \\
\text { facilities, launch of production), mln rub }\end{array}$ \\
\hline & & Expected monetary value, $\mathrm{mln}$ rub \\
\hline & & Net present value, mln rub \\
\hline & & Budget efficiency, mln rub \\
\hline & & Return on investment \\
\hline & & Internal rate of return, $\%$ \\
\hline & & Payback period, years \\
\hline & & Unit total cost, mln rub \\
\hline
\end{tabular}


Table 3. Cont.

\begin{tabular}{|c|c|c|}
\hline & proach & Indicators \\
\hline \multirow{20}{*}{ Sustainability } & \multirow{8}{*}{ Social indicators } & The number of highly efficient jobs, units \\
\hline & & Contribution to the socio-economic development of the region \\
\hline & & Improving the living standards of the population \\
\hline & & Degree of public involvement in decision making \\
\hline & & New competencies \\
\hline & & Indicator of the average level of wages, rub \\
\hline & & Standard of living \\
\hline & & Implementation of programs aimed at improving the qualifications of personnel, units \\
\hline & \multirow{12}{*}{$\begin{array}{l}\text { Environmental } \\
\text { indicators }\end{array}$} & Energy intensity, \% \\
\hline & & Resource efficiency, \% \\
\hline & & $\begin{array}{c}\text { Prevented damage: (rub/year) } \\
\text {-water resources; } \\
\text {-air; } \\
\text {-land resources (soil and land degradation); } \\
\text {-bioresources }\end{array}$ \\
\hline & & Resource intensity indicator, $\%$ \\
\hline & & Carbon content, $\%$ \\
\hline & & Waste capacity indicator, $\%$ \\
\hline & & Water capacity indicator, $\%$ \\
\hline & & Indicator of the degree of involvement of waste in production, $\%$ \\
\hline & & Indicator of the level of purification of emissions of pollutants into the atmosphere, $\%$ \\
\hline & & Indicator of innovative technologies, the level of technological support \\
\hline & & Accident rate (assessment of the likelihood of potential environmental threats) \\
\hline & & Creation of insurance funds to prevent possible environmental damage \\
\hline \multirow{17}{*}{$\begin{array}{c}\text { Strategic } \\
\text { sustainability }\end{array}$} & \multirow{6}{*}{$\begin{array}{l}\text { Sensitivity to trends } \\
\text { and volatility }\end{array}$} & Strengthening competition in traditional hydrocarbon markets \\
\hline & & Transition to low-carbon development $[2,116]$ \\
\hline & & Growing role of innovation (technologies) \\
\hline & & Increasing role of digitalization \\
\hline & & Social awareness \\
\hline & & Environmental safety \\
\hline & \multirow{6}{*}{$\begin{array}{l}\text { Contribution to the } \\
\text { achievement of the } \\
\text { global SDGs }\end{array}$} & SDG 3. Good health and well-being \\
\hline & & SDG 9. Industrialization, innovation, and infrastructure \\
\hline & & SDG 11. Sustainable cities and towns \\
\hline & & SDG 12. Responsible consumption and production \\
\hline & & SDG 14. Conservation of marine ecosystems \\
\hline & & SDG 17. Partnership for sustainable development \\
\hline & \multirow{5}{*}{$\begin{array}{l}\text { Commitment to ESG } \\
\text { factors }\end{array}$} & Effectiveness of corporate governance \\
\hline & & Corporate and social responsibility \\
\hline & & Business reputation \\
\hline & & Cooperative ventures with the government \\
\hline & & Effectiveness of the risk management system \\
\hline
\end{tabular}




\section{Discussion}

It is well-known that exploration of the Arctic's resource potential remains a deliberative issue. There is an opinion that resource exploitation cannot be sustainable for the Arctic region, as any industrial activity influences the environment [135]. In view of the low-carbon development and green trends, offshore projects are often discussed as unsustainable. Obviously, the production processes influence the fragility of the Arctic's ecosystems. However, these reserves can be considered as strategically important not only for Russia, but for the whole world. Traditional energy sources are gradually being depleted. This leads to the necessity of searching for new resources-both conventional and unconventional.

We assume that in energy equivalent, the increase in alternative energy sources does not compensate for the growth in the global energy consumption. Therefore, Arctic hydrocarbon resources can be vital for meeting the future needs. The issue is that they are unique, making traditional technologies and approaches unfit. The interest in implementing Arctic offshore projects is increasing with growth in prices. However, consideration of these projects only from the economic point of view is fundamentally wrong. The high level of environmental risks, severe conditions, etc., must be taken into account. We argue that in the current conditions, Arctic offshore projects can only be effective if they comply with all novel standards and requirements. As we noted above, economic efficiency is an important pillar, but it is not the only one. In order to tackle new challenges, follow new trends, and be supported, Arctic projects have to be sustainable.

The analysis of scientific literature has shown a lot of different approaches towards project sustainability and strategic sustainability in particular. The paper does not contradict previous studies but complements them by revealing the nature of the strategic sustainability concept, its adaptation to oil and gas projects, and its key principles and features.

We have tried to build upon current approaches and principles, and to develop our own vision of how Arctic projects can be strategically sustainable in such trends as the focus on green economics, the global energy transition, the growing importance of social and environmental pillars, and novel investment standards. We have shown that the current approaches towards sustainability have to be transformed as they do not meet the existing challenges.

We have developed a list of indicators to determine Arctic projects' strategic sustainability taking into consideration their specifics. These indicators are different and include both qualitative and quantitative ones. In this research, we have tried to present a conceptual framework. Therefore, we do not attempt to assess particular projects, leaving this task for our further research.

\section{Conclusions}

Nowadays, the not yet explored potential of hydrocarbons in the Russian Arctic is 91\% offshore and 53\% onshore [136]. The low rates of exploitation of Arctic deposits are due to the features of development activities in the Arctic Circle. Challenging geological and weather conditions, poor infrastructure and logistics, and the vulnerable environment require special approaches to the technological systems and competencies used. Low prices for energy resources, as well as the lack of access to foreign technologies and financing, reduce the profitability and investment attractiveness of production activities $[137,138]$. In addition, the production and transportation of hydrocarbons in the Arctic, especially offshore, are associated with a negative impact on ecosystems and possible man-made disasters. Therefore, today, the implementation of high-risk capital-intensive oil and gas projects in the Arctic is a truly global challenge for both Russian oil and gas companies and the government in the context of the crisis in the global economy, structural changes in the energy mix, and the growing role of low-carbon development.

Given the transition to green energy on the one hand, and the continuing demand for oil and gas resources on the other, Russia has the opportunity to expand its capacity 
through Arctic offshore projects. At the same time, their implementation requires a special approach, which should take into account the following issues:

- $\quad$ to develop long-term strategies including the ways and actions to meet key global challenges (related to low-carbon development in particular);

- $\quad$ to represent the contribution to the environmental and social aspects;

- $\quad$ to focus on the technological advances (to minimize possible environmental risks, to reduce production costs, to maintain a competitive position on the global market);

- $\quad$ to create new approaches to interact with the key stakeholders;

- $\quad$ to show commitment to the SDGs (not only in theory but also in practice).

The above mentioned will help to ensure the strategic sustainability of Arctic projects.

According to the background and the purpose of the research, we suggest a conceptual framework of strategic sustainability of Arctic offshore projects that requires a transformation of the existing approaches. It involves integrating SD principles, adaptability to emerging challenges, and new opportunities by building up novel competitive advantages, changing approaches to strategic management, and following the pace of scientific and technological progress. The following directions were determined:

- Designing a system of flexible indicators for assessing environmental, social, and economic variables;

- Integrating SDG and ESG factors into strategic management systems;

- $\quad$ Correlation between project investment attractiveness and the degree of responsibility and commitment on SD principles;

- $\quad$ The key goal is to achieve multiplier effects; the main criterion is adherence to the SDGs (responsible business practices) and adaptability to the conditions of a turbulent macroenvironment.

It has been determined that the analysis of the strategic sustainability of Arctic offshore projects should include performance indicators, stability parameters, as well as criteria for compliance with trends, ESG criteria, and criteria for contribution to the achievement of the SDGs.

Author Contributions: Conceptualization, D.D.; methodology, D.D. and A.C.; formal analysis, G.S. and V.S.; investigation, D.D.; data curation, V.S.; writing-original draft preparation, D.D.; writingreview and editing, A.C. and G.S.; visualization, V.S.; supervision, D.D. All authors have read and agreed to the published version of the manuscript.

Funding: The research was performed at the expense of the subsidy for the state assignment in the field of scientific activity for 2021 №FSRW-2020-0014.

Institutional Review Board Statement: Not applicable.

Informed Consent Statement: Not applicable.

Data Availability Statement: Data sharing not applicable.

Conflicts of Interest: The authors declare no conflict of interest.

\section{Appendix A}

Table A1. Sensitivity towards trends and volatility.

\begin{tabular}{cccc}
\hline $\begin{array}{c}\text { Novel Trends and } \\
\text { Challenges }\end{array}$ & $\mathbf{0}$ & $\mathbf{1}$ & $\mathbf{2}$ \\
\cline { 2 - 4 } & \multicolumn{3}{c}{ Sensitivity towards Trends, Scores } \\
\hline $\begin{array}{c}\text { Strengthening competition in } \\
\text { traditional hydrocarbon } \\
\text { markets }\end{array}$ & $\begin{array}{c}\text { A company has significant } \\
\text { competitive advantages, holds } \\
\text { a stable position in the market }\end{array}$ & $\begin{array}{c}\text { A company has significant } \\
\text { competitive advantages, but } \\
\text { its position in the global } \\
\text { market is unstable }\end{array}$ & $\begin{array}{c}\text { A company loses its } \\
\text { competitive position and } \\
\text { cannot compete with other } \\
\text { market players }\end{array}$ \\
\hline
\end{tabular}


Table A1. Cont.

\begin{tabular}{|c|c|c|c|}
\hline \multirow{2}{*}{$\begin{array}{l}\text { Novel Trends and } \\
\text { Challenges }\end{array}$} & \multicolumn{3}{|c|}{ Sensitivity towards Trends, Scores } \\
\hline & $\mathbf{0}$ & 1 & 2 \\
\hline $\begin{array}{c}\text { Transition to low-carbon } \\
\text { development }\end{array}$ & $\begin{array}{l}\text { The project priorities are fully } \\
\text { aligned with the targets of the } \\
\text { global energy transition }\end{array}$ & $\begin{array}{l}\text { A company attempts to } \\
\text { diversify its activities in favor } \\
\text { of green assets and introduces } \\
\text { advanced technologies for } \\
\text { sequestration of } \mathrm{CO}_{2}\end{array}$ & $\begin{array}{c}\text { Project priorities completely } \\
\text { contradict with the } \\
\text { low-carbon development } \\
\text { vision }\end{array}$ \\
\hline $\begin{array}{l}\text { Growing role of innovations } \\
\text { (technologies) }\end{array}$ & $\begin{array}{l}\text { Use of advanced technologies, } \\
\text { high innovative activity }\end{array}$ & $\begin{array}{l}\text { Partial implementation of } \\
\text { innovative technologies at the } \\
\text { level of individual production } \\
\text { and production processes }\end{array}$ & $\begin{array}{l}\text { Low innovation activity, } \\
\text { outdated technologies, high } \\
\text { depreciation of fixed assets }\end{array}$ \\
\hline Growing role of digitalization & $\begin{array}{l}\text { Widespread use of advantages } \\
\text { of digitalization, full } \\
\text { automation of production and } \\
\text { technological processes } \\
\text { ("smart field") }\end{array}$ & $\begin{array}{l}\text { Partial use of digital solutions } \\
\text { when performing certain } \\
\text { operations, partial automation } \\
\text { of production and } \\
\text { technological processes }\end{array}$ & $\begin{array}{c}\text { Lack of digital solutions in the } \\
\text { organization of production } \\
\text { and production processes }\end{array}$ \\
\hline Social awareness & $\begin{array}{l}\text { Practical implementation of } \\
\text { socially responsible business } \\
\text { concepts, use of progressive } \\
\text { methods and tools for } \\
\text { interaction with the public }\end{array}$ & $\begin{array}{l}\text { Prerequisites for the } \\
\text { implementation of socially } \\
\text { responsible business concepts }\end{array}$ & $\begin{array}{l}\text { Lack of effective interaction } \\
\text { between the company and } \\
\text { society }\end{array}$ \\
\hline Environmental safety & $\begin{array}{l}\text { Minimizing potential threats } \\
\text { to environmental safety, } \\
\text { continuous monitoring }\end{array}$ & $\begin{array}{l}\text { Building an effective system } \\
\text { for preventing environmental } \\
\text { consequences }\end{array}$ & $\begin{array}{l}\text { High level of environmental } \\
\text { threats and risks, lack of } \\
\text { effective oil spill prevention } \\
\text { systems }\end{array}$ \\
\hline
\end{tabular}

\section{References}

1. Ryser, J. Pandemic Has Accelerated Transition to Low-Carbon Economy: Moody's. 2020. Available online: https: //www.spglobal.com/platts/en/market-insights/latest-news/electric-power/102220-pandemic-has-accelerated-transitionto-low-carbon-economy-moodys (accessed on 28 July 2021).

2. The Oxford Institute for Energy Studies. The Rise of Renewables and Energy Transition: What Adaptation Strategy for Oil Companies and Oil-Exporting Countries? 2018. Available online: https://www.oxfordenergy.org/wpcms/wp-content/uploads/2018 /05/The-rise-of-renewables-and-energy-transition-what-adaptation-strategy-for-oil-companies-and-oil-exporting-countriesMEP-19.pdf (accessed on 30 August 2021).

3. Turbulent Outlook for Energy. 2020. Available online: https://www.energy-transition-institute.com/documents/17779499/1778192 1/06_Turbulent_outlook_for_energy.pdf/9307e8dd-0ece-244a-caf8-721125aed09f?t=1588099906000 (accessed on 24 October 2021).

4. Moscow School of Management Skolkovo. Coronacrisis: The Impact of COVID-19 on the Fuel and Energy Sector in the World and in Russia. 2020. Available online: https://mks-group.ru/storage/presentations/SKOLKOVO_EneC_COVID1 9_and_Energy_sector_RU.pdf (accessed on 2 August 2021).

5. Crude Oil Price Forecast: 2021, 2022 and Long Term to 2050. 2021. Available online: https:/ /knoema.ru/infographics/yxptpab/ crude-oil-price-forecast-2021-2022-and-long-term-to-2050 (accessed on 15 October 2021).

6. U.S. Short Term Energy Outlook, April 2021. 2021. Available online: https:// knoema.com/EIASTEO2021APR/u-s-short-termenergy-outlook-april-2021 (accessed on 24 October 2021).

7. Canada's Energy Future 2020. Canada Energy Regulator. 2020. Available online: https://www.cer-rec.gc.ca/en/data-analysis/ canada-energy-future/2020/ canada-energy-futures-2020.pdf (accessed on 24 October 2021).

8. World Economic Outlook Database 2021. 2021. Available online: https://www.imf.org/en/Publications/WEO/weo-database/ 2021/October (accessed on 18 October 2021).

9. International Energy Agency (IEA). Global Energy Review 2021. 2021. Available online: https://www.iea.org/reports/globalenergy-review-2021 (accessed on 23 July 2021).

10. Organization of the Petroleum Exporting Countries (OPEC). World Oil Outlook 2045. 2021. Available online: https:/ /woo.opec. org (accessed on 24 July 2021).

11. Rystad Energy. Covid-19 and Energy Transition Will Expedite Peak Oil Demand to 2028 and Cut Level to 102 Million Bpd. 2020. Available online: https:/ / www.rystadenergy.com/newsevents/news/press-releases/covid-19-and-energy-transitionwill-expedite-peak-oil-demand-to-2028-and-cut-level-to-102-million-bpd (accessed on 23 July 2021). 
12. BP Energy Outlook: 2020 Edition. 2020. Available online: https://www.bp.com/content/dam/bp/business-sites/en/global/ corporate/pdfs/energy-economics/energy-outlook/bp-energy-outlook-2020.pdf (accessed on 22 July 2021).

13. The Green Course of Russia. Greenpeace. 2020. Available online: https://greenpeace.ru/wp-content/uploads/2020/09/GC_A4 _006.pdf (accessed on 24 July 2021).

14. Golovina, E.I. Environmental peculiarities of transboundary groundwater management. Int. J. Mech. Eng. 2019, 10, 511-519.

15. DNV GL Energy Transition Outlook 2020. 2020. Available online: https://www.dnv.com/Publications/energy-transitionoutlook-2020-186774 (accessed on 24 July 2021).

16. BP Statistical Review of World Energy 69th Edition. 2020. Available online: https://www.bp.com/content/dam/bp/business-sites/ en/global/corporate/pdfs/energy-economics/statistical-review/bp-stats-review-2020-full-report.pdf (accessed on 24 July 2021).

17. Grushevenko, E.; Kapitonov, S.; Melnilkov, Y.; Perdereau, A.; Sheveleva, N.; Siginevich, D. Decarbonization of Oil and Gas: International Experience and Russian Priorities; Skolkovo School of Management: Skolkovo, Russia, 2021. Available online: https: / / energy. skolkovo.ru/downloads/documents/SEneC/Research/SKOLKOVO_EneC_Decarbonization_of_oil_and_gas_EN_22032021.pdf (accessed on 28 July 2021).

18. OECD. Oil 2020 Analysis and Forecast to 2025. 2020. Available online: https://www.oecd.org/publications / market-reportseries-oil-25202707.htm (accessed on 30 July 2021).

19. Westwood Global Energy. 2020 High Impact Exploration and 2021 Key Wells to Watch. 2021. Available online: https://www. westwoodenergy.com/news/westwood-insight/2020-high-impact-exploration-and-2021-key-wells-to-watch (accessed on 22 July 2021).

20. Balashova, E.S.; Gromova, E.A. Arctic shelf development as a driver of the progress of the Russian energy system. MATEC Web Conf. 2017, 106, 06008:1-06008:6. [CrossRef]

21. Carayannis, E.G.; Cherepovitsyn, A.E.; Ilinova, A.A. Sustainable development of the Russian Arctic zone energy shelf: The role of the Quintuple Innovation Helix Model. J. Knowl. Econ. 2017, 8, 456-470. [CrossRef]

22. Kapustin, A. From fragmentation to complex regulation. Law and development of oil and gas resources of the Russian Arctic and the continental shelf. Neftegaz. RU 2020, 5, 20-25.

23. Decree of the President of the Russian Federation No. 645 of 26 October 2021. On the Strategy for the Development of the Arctic Zone of the Russian Federation and Ensuring National Security for the Period up to 2035. 2021. Available online: https:/ / www.gov.spb.ru/static/writable/ckeditor/uploads/2020/11/24/01/Стратегия_Арктика_2035.pdf (accessed on 29 September 2021).

24. Cherepovitsyn, A.E.; Tsvetkova, A.Y.; Komendantova, N.E. Approaches to assessing the strategic sustainability of high-risk offshore oil and gas projects. J. Mar. Sci. Eng. 2020, 8, 995. [CrossRef]

25. Shestak, O.; Shcheka, O.L.; Klochkov, Y. Methodological aspects of use of countries experience in determining the directions of the strategic development of the Russian Federation Arctic regions. Int. J. Syst. Assur. Eng. Manag. 2020, 11, 44-62. [CrossRef]

26. Papenov, K.V.; Nikonorov, S.M. Theoretical and practical problems of Arctic development. Arct. 2035 Actual Issues Probl. Solut. 2020, 3, 64-75. [CrossRef]

27. Henderson, J.; Grushevenko, E. The Future of Russian Oil Production in the Short, Medium, and Long Term; The Oxford Institute for Energy Studies: Oxford, UK, 2019. Available online: https://www.oxfordenergy.org/wpcms/wp-content/uploads/2019/09/ The-Future-of-Russian-Oil-Production-in-the-Short-Medium-and-Long-Term-Insight-57.pdf (accessed on 25 July 2021).

28. Gritsenko, D.; Efimova, E. Is there Arctic resource curse? Evidence from the Russian Arctic regions. Resour. Policy 2020, 65, 101547. [CrossRef]

29. Kobylkin, D.N. The resources of the Arctic shelf are our strategic reserve. Energy Policy 2019, 3, 6-9.

30. Morgunova, M.O. Why is exploitation of Arctic offshore oil and natural gas resources ongoing? A multi-level perspective on the cases of Norway and Russia. Polar J. 2020, 9, 64-81. [CrossRef]

31. Gielen, D.; Boshell, F.; Saygin, D.; Bazilian, M.; Wagner, N.; Gorini, R. The role of renewable energy in the global energy transformation. Energy Strategy Rev. 2019, 24, 38-50. [CrossRef]

32. Brazovskaia, V.; Gutman, S.; Zaytsev, A. Potential impact of renewable energy on the sustainable development of Russian Arctic territories. Energies 2021, 14, 3691. [CrossRef]

33. Grigoriev, G.A. Prospects for the development of hydrocarbon resources of the Russian Arctic shelf-A strategic pause is inevitable. Miner. Resour. Russia. Econ. Manag. 2019, 2, 37-45.

34. Yurak, V.V.; Dushin, A.V.; Mochalova, L.A. Vs sustainable development: Scenarios for the future. J. Min. Inst. 2020, $242,242-247$. [CrossRef]

35. Nazarov, V.; Krasnov, O.; Medvedeva, L. The Arctic oil and gas shelf of Russia at the stage of changing the world energy basis. Energy Policy 2021, 7, 70-85. [CrossRef]

36. Fadeev, A.M.; Lipina, S.A.; Zaikov, K.S. Innovative approaches to environmental management in the development of hydrocarbons in the Arctic shelf. Polar J. 2021, 11, 208-229. [CrossRef]

37. Shabalov, M.Y.; Dmitrieva, D.M. Implementation of cluster scenario approach for economic development of The Arctic zone of The Russian Federation. Int. J. Appl. Bus. Econ. Res. 2017, 15, 281-289.

38. Palosaari, T. The Arctic paradox (and how to solve it). Oil, gas and climate ethics in the Arctic. In The GlobalArctic Handbook; Finger, M., Heininen, L., Eds.; Springer International Publishing: Cham, Switzerland, 2019; pp. 141-152. 
39. Bogoyavlensky, V.I.; Bogoyavlensky, I.V. Development of hydrocarbon resources and environmental safety in the Arctic. Arct. Vedom. 2021, 1, 30-43.

40. Brekhuntsov, A.M.; Petrov, Y.V.; Prykova, O.A. Ecological aspects of the development of the natural resource potential of the Russian Arctic. Arct. Ecol. Econ. 2020, 3, 34-47. [CrossRef]

41. Nikolaichuk, L.; Tcvetkov, P. Prospects of ecological technologies development in the Russian oil industry. Int. J. Appl. Eng. Res. 2016, 11, 5271-5276.

42. Morgunova, M.; Kovalenko, A. Energy innovations in the Arctic. Energy Policy 2021, 4, 30-43. [CrossRef]

43. Litvinenko, V.; Meyer, B. Syngas Production: Status and Potential for Implementation in Russian Industry; Springer International Publishing: Cham, Switzerland, 2017; 161p, ISBN 978-3-319-89022-7.

44. Dmitrieva, D.M.; Romasheva, N.V. Sustainable development of oil and gas potential of the Arctic and its shelf zone: The role of innovations. J. Mar. Sci. Eng. 2020, 12, 1003. [CrossRef]

45. Strategy\&. 2020 Digital Operations Study for Energy. 2020. Available online: https://www.strategyand.pwc.com/gx/en/ insights/2020/digital-operations-study-for-oil-and-gas/2020-digital-operations-study-for-energy-oil-and-gas.pdf (accessed on 29 July 2021).

46. D'Adamo, I. Adopting a circular economy: Current practices and future perspectives. Soc. Sci. 2019, 8, 328. [CrossRef]

47. Shi, L.; Han, L.; Yang, F.; Gao, L. The evolution of sustainable development theory: Types, goals, and research prospects. Sustainability 2019, 11, 7158. [CrossRef]

48. Ghisellini, P.; Catia, C.; Sergio, U. A review on circular economy: The expected transition to a balanced interplay of environmental and economic systems. J. Clean. Prod. 2016, 114, 11-32. [CrossRef]

49. Lahti, T.; Wincent, J.; Parida, V. A Definition and theoretical review of the circular economy, value creation, and sustainable business models: Where are we now and where should research move in the future? Sustainability 2018, 10, 2799. [CrossRef]

50. Söderholm, P. The green economy transition: The challenges of technological change for sustainability. Sustain. Earth 2020, 3 , 1-11. [CrossRef]

51. Ponomarenko, T.; Nevskaya, M.; Marinina, O. An assessment of the applicability of sustainability measurement tools to resourcebased economies of the Commonwealth of Independent States. Sustainability 2020, 12, 5582. [CrossRef]

52. Huckle, J.; Wals, A. The UN decade of education for sustainable development: Business as usual in the end. Environ. Educ. Res. 2015, 21, 491-505. [CrossRef]

53. United Nations General Assembly. Resolution Adopted by the General Assembly on 16 September 2005. 2005. Available online: https://www.un.org/en/development/desa/population/migration/generalassembly/docs/globalcompact/A_RES_6 0_1.pdf (accessed on 10 September 2021).

54. Morton, S.; Pencheon, D.; Squires, N. Sustainable Development Goals (SDGs), and their implementation. Br. Med. Bull. 2017, 124, 81-90. [CrossRef]

55. Rockström, J.; Bai, X.; DeVries, B. Global sustainability: The challenge ahead. Glob. Sustain. 2018, 1, 1-3. [CrossRef]

56. Eggert, R. Mining, sustainability, and sustainable development. In Mineral Economics, 2nd ed.; Maxwell, P., Ed.; Australasian Institute of Mining and Metallurgy: Carlton, Australia, 2013; pp. 215-227, ISBN 978-1-921522-87-1.

57. Choi, Y.; Song, J. Sustainable development of abandoned mine areas using renewable energy systems: A case study of the photovoltaic potential assessment at the Tailings Dam of abandoned Sangdong Mine, Korea. Sustainability 2016, 8, 1320. [CrossRef]

58. Mesquita, M.J.; Corazza, R.I.; Souza, M.C.O.; Gomes, G.N.; Noronha, I.; Macedo, D. Mining and sustainability. In Environmental Sustainability, 1st ed.; da Cal Seixas, S.R., de Moraes Hoefel, J.L., Eds.; CRC Press: Boca Raton, FL, USA, 2021; 25p, ISBN 978-0367861698.

59. Randall, A. Resource scarcity and sustainability-The shapes have shifted but the stakes keep rising. Sustainability 2021, 13, 5751. [CrossRef]

60. Diesendorf, M. Sustainability and sustainable development. In Sustainability: The Corporate Challenge of the 21st Century; Dunphy, D., Benveniste, J., Griffiths, A., Sutton, P., Eds.; Allen\&Unwin: Sydney, Australia, 2000; pp. 19-37, ISBN 978-1865082288.

61. Khalili, N.R. Theory and concept of sustainability and sustainable development. In Practical Sustainability; Palgrave Macmillan: New York, NY, USA, 2011; pp. 1-22. [CrossRef]

62. Jeronen, E. Sustainability and sustainable development. In Encyclopedia of Corporate Social Responsibility; Idowu, S.O., Capaldi, N., Zu, L., Gupta, A.D., Eds.; Springer: Berlin/Heidelberg, Germany, 2013; pp. 2370-2378, ISBN 978-3-642-28035-1.

63. Sakalasooriya, N. Conceptual analysis of sustainability and sustainable development. Open J. Soc. Sci. 2021, 9, 396-414. [CrossRef]

64. Otto, S. What means sustainability and sustainable development? ÖkologischesWirtschaften 2010, 4, 35-38. [CrossRef]

65. Rout, P.R.; Verma, A.K.; Bhunia, P.; Surampalli, R.Y.; Zhang, T.C.; Tyagi, R.D.; Goyal, M.K. Introduction to sustainability and sustainable development. In Sustainability: Fundamentals and Applications, 1st ed.; Surampalli, R.Y., Zhang, T.C., Goyal, M.K., Brar, S.K., Tyagi, R.D., Eds.; Wiley: Hoboken, NJ, USA, 2020; pp. 1-19, ISBN 978-1-119-43396-5.

66. Sharmin, S. On "sustainable development" and "sustainability": Different explanations and meanings. J. Indian Res. 2016, 4, 56-72.

67. Mariani, A.; Vastola, A. Sustainable winegrowing: Current perspectives. Int. J. Wine Res. 2015, 7, 37-48. [CrossRef]

68. United Nations Educational, Scientific and Cultural Organization. UNESCO Moving Forward the 2030 Agenda for Sustainable Development. 2017. Available online: https://en.unesco.org/creativity/sites/creativity/files/247785en.pdf (accessed on 13 July 2021). 
69. Chatterjee, K.K. Sustainability and sustainable development of mineral resources. In Macro-Economics of Mineral and Water Resources; Springer International Publishing: Cham, Switzerland; Capital Publishing Company: New Delhi, India, 2015; pp. 161-188, ISBN 978-3-319-15053-6.

70. Ancione, G.; Paltrinieri, N.; Milazzo, M.F. Integrating real-time monitoring data in risk assessment for crane related offshore operations. J. Mar. Sci. Eng. 2020, 8, 532. [CrossRef]

71. Liu, Y.; Ren, J. Overview of sustainability, sustainable development and sustainability assessment: Concepts and methods. In Energy Systems Evaluation. Green Energy and Technology; Ren, J., Ed.; Springer International Publishing: Cham, Switzerland, 2021; Volume 1, pp. 1-29, ISBN 978-3-030-67528-8.

72. Beder, S. Costing the earth: Equity, sustainable development and environmental economics. N. Z. J. Environ. Law 2000, 4, 227-243.

73. Beder, S. The stain in sustainability. New Int. 2005, 383, 14-15.

74. Ruggerio, C.A. Sustainability and sustainable development: A review of principles and definitions. Sci. Total Environ. 2021, 786, 147481. [CrossRef] [PubMed]

75. Tan, Y.S.; Kwek, L.J. Environmental sustainability and sustainable development. In 50 Years of Environment: Singapore's Journey Towards Environmental Sustainability; Tan, Y.S., Ed.; World Scientific Publishing: Singapore, 2015; pp. 247-264, ISBN 978-9814696210.

76. Connelly, S.; Markey, S.; Roseland, M. Strategic sustainability: Addressing the community infrastructure deficit. Can. J. Urban Res. 2009, 18, 1-23.

77. Telesford, J.N.; Strachan, P.A. Strategic sustainability procedures: Focusing business strategic planning on the socio-ecological system in an island context. Sustain. Dev. 2016, 25, 35-49. [CrossRef]

78. Kwon, M.; Tang, S.-Y.; Kim, C. Examining strategic sustainability plans and smart-growth land-use measures in California cities. J. Environ. Plan. Manag. 2017, 61, 1570-1593. [CrossRef]

79. Da Rocha Vencato, C.H.; Gomes, C.M.; Scherer, F.L.; Kneipp, J.M.; Bichueti, R.S. Strategic sustainability management and export performance. Manag. Environ. Qual. 2014, 25, 431-445. [CrossRef]

80. Lacy, P.; Cooper, T.; Hayward, R.; Neuberger, L. A New Era of Sustainability: UN Global Compact-Accenture CEO Study 2010 2010. Available online: www.unglobalcompact.org/docs/news_events/8.1/UNGC_Accenture_CEO_Study_2010.pdf (accessed on 25 June 2021)

81. Evans, A.; Strezov, V.; Evans, T.J. Assessment of sustainability indicators for renewable energy technologies. Renew. Sustain. Energy Rev. 2009, 13, 1082-1088. [CrossRef]

82. Broman, G.; Robèrt, K. A Framework for strategic sustainable development. J. Clean. Prod. 2015, 140, 17-31. [CrossRef]

83. Malenkov, Y.; Kapustina, I.; Shishkin, V.; Shishkin, V. Theoretical aspects of strategic sustainability of a trading enterprise under digitally transforming economy. IOP Conf. Ser. Mater. Sci. Eng. 2019, 497, 012128. [CrossRef]

84. Singh, R.; Murty, H.R.; Gupta, S.K.; Dikshit, A. An overview of sustainability assessment methodologies. Ecol. Indic. 2009, 9, 189-212. [CrossRef]

85. Presley, A.; Meade, L.; Sarkis, J. A strategic sustainability justification methodology for organizational decisions: A reverse logistics illustration. Int. J. Prod. Res. 2007, 45, 4594-4620. [CrossRef]

86. Hallstedt, S.; Thompson, A.; Lindahl, P. Key elements for implementing a strategic sustainability perspective in the product innovation process. J. Clean. Prod. 2013, 51, 277-288. [CrossRef]

87. Schade, W.; Rothengatter, W. Strategic sustainability analysis: Broadening existing assessment approaches for transport policies. Transp. Res. Rec. 2001, 1756, 3-11. [CrossRef]

88. Smith, A.D. Strategic sustainability and operational efficiency dilemma of data centres. Int. J. Bus. Inf. Syst. 2011, 8, 107-130. [CrossRef]

89. Russia Maritime Studies Institute. Foundations of the Russian Federation State Policy in the Arctic for the Period Up to 2035 2020. Available online: https://dnnlgwick.blob.core.windows.net/portals/0/NWCDepartments/Russia $\% 20 \mathrm{Maritime} \% 20$ Studies\%20Institute/ArcticPolicyFoundations2035_English_FINAL_21July2020.pdf?sr=b\&si=DNNFileManagerPolicy\&sig= DSkBpDNhHsgjOAvPILTRoxIfV\%2FO02gR81NJSokwx2EM\%3D (accessed on 15 October 2021).

90. WWF. Arctic Oil and Gas. 2021. Available online: https://arcticwwf.org/work/oil-and-gas (accessed on 12 September 2021).

91. Conservation of Arctic Flora and Fauna (CAFF). Arctic Biodiversity Assessment: Status and Trends in Arctic Biodiversity. 2013. Available online: https://portals.iucn.org/library/sites/library/files/documents/Bios-Eco-Ter-Pol-027.pdf (accessed on 3 October 2021).

92. Integrated Climate Change Strategies for Sustainable Development of Russia's Arctic Regions. Case Study for Murmansk Oblast. 2009. Available online: https://research.fit.edu/media/site-specific/researchfitedu/coast-climate-adaptation-library/ europe/russia-ukraine-georgia/Rrec--Undp.-2009.-Russia-Arctic-Sustainable-Development--CC-[in-Russian].pdf (accessed on 15 September 2021).

93. Korchak, E.A.; Serova, N.A. Polar views on the Arctic: The Arctic policy of Russia and foreign countries. Contours Glob. Transform. Politics Econ. Law 2019, 12, 145-159. [CrossRef]

94. Gassiy, V.; Sleptsov, A. Russian Arctic ecosystem sustainability in rapid changes and challenges. E3S Web Conf. 2021, 291, 02010. [CrossRef]

95. Foresight Study of the Development of the Arctic Offshore Industry Until 2030. 2021. Available online: https://www.dvfu. $\mathrm{ru} /$ schools/engineering/structure/research-and-education-centers/international_scientific_educational_center_r_d_center_ arktika/foresight-study-of-the-development-of-arctic-offshore-industry-up-to-2030 (accessed on 16 September 2021). 
96. Fadeev, A.M.; Cherepovitsyn, A.E.; Larichkin, F.D. Strategic Management of the Oil and Gas Complex in the Arctic; KSC RAS: Apatity, Russia, 2019; 289p, ISBN 978-5-91137-407-5.

97. Challenges and Opportunities of Oil and Gas Investment in the Arctic. 2015. Available online: https://sipa.columbia.edu/sites/ default/files/downloads/Barclays_Final\%20Report.pdf (accessed on 5 September 2021).

98. Stipo, F.; Thorhaug, A.; Jackson, R.; Butler, K.; Gibbs, R.; Gray, J.; Marshall, P.; Oerke, A.; Simion, M.; White, L.; et al. The future of the Arctic: A key to global sustainability. Cadmus 2012, 42, 47-48.

99. Verhaag, M.A. It is not too late: The need for a comprehensive international treaty to protect the Arctic environment. Georget. Int. Environ. Law Rev. 2003, 15, 555-579.

100. Ocean Conservatory. 2021. Available online: https:/ / oceanconservancy.org/programs (accessed on 14 August 2021).

101. Rixey, C.M. Oil and Sustainability in the Arctic Circle. Denver J. Int. Law Policy 2016, 44, $441-452$.

102. Lee, O. Effect of corporate sustainability policies and investment risks for future Arctic oil and gas development in Alaska. 2020. Available online: https://arcticyearbook.com/images/yearbook/2020/Scholarly-Papers/2_Lee.pdf (accessed on 4 September 2021).

103. Nikitina, O. Shelf formula. Sib. Oil 2016, 129, 38-41.

104. Gazeev, M.H.; Volynskaya, N.A.; Rybak, A.B. Complex Efficiency Assessment of Development of Arctic Oil \& Gas Resources in Russia. 2018. Available online: https://arcticyearbook.com/arctic-yearbook/2018/2018-scholarly-papers/289-complexefficiency-assessment-of-development-of-arctic-oil-gas-resources-in-russia (accessed on 16 September 2021).

105. Shibata, A.; Chuffart, R. Sustainability as an integrative principle: The role of international law in Arctic resource development. Polar Rec. 2020, 56, E37. [CrossRef]

106. Degtyareva, E.V. Economic effects of the Arctic continental shelf development. In IOP Conference Series: Earth and Environmental Science,. 4th International Scientific Conference "Arctic: History and Modernity", Saint Petersburg, Russian Federation, 17-18 April 2019; IOP Publishing: Bristol, UK, 2019; Volume 302, p. 012136. [CrossRef]

107. Sustainable Development Goals in the Arctic. 2021. Available online: https://arctic-council.org/ru/projects/sustainabledevelopment-goals-in-the-arctic (accessed on 1 October 2021).

108. Mineev, A.; Timoshenko, A.; Zhurova, E.; Middleton, A. Implementering av FNs bærekraftsmål i det norske Arktis: Et fiks ferdig rammeverk? Magma 2020, 5, 74-85.

109. Sustainable Development Action-The Nordic Way. 2017. Available online: https://norden.diva-portal.org/smash/get/diva2: 1092868/FULLTEXT01.pdf (accessed on 6 September 2021).

110. Nedosekin, A.O.; Rejshahrit, E.I.; Kozlovskij, A.N. Strategic approach to assessing economic sustainability objects of mineral resources sector of Russia. J. Min. Inst. 2019, 237, 354-360. [CrossRef]

111. Kneen, J. Earth: What is Mining All About? The Up and Down Sides. 2007. Available online: https://miningwatch.ca/sites/ default/files/Mining_Unsustainable_0.pdf (accessed on 13 October 2021).

112. Hoff, M. Can Mining be Sustainable? 2013. Available online: https://ensia.com/articles/mine-over-matter (accessed on 5 October 2021).

113. The Big Choices for Oil and Gas in Navigating the Energy Transition. 2021. Available online: https://www.mckinsey. com/industries/oil-and-gas/our-insights/the-big-choices-for-oil-and-gas-in-navigating-the-energy-transition (accessed on 10 September 2021).

114. Norway's Arctic Strategy: Innovation and Sustainability. 2016. Available online: https://www.openaccessgovernment.org/ norways-arctic-strategy-innovation-sustainability/30391 (accessed on 14 September 2021).

115. Dudin, M.N.; Lyasnikov, N.V.; Sekerin, V.D.; Gorohova, A.E.; Bank, S.V. Provision of global economic and energy security in the context of the development of the Arctic resource base by industrialized countries. Int. J. Econ. Financ. Issues 2015, 5, 248-256.

116. The 2030 Decarbonization Challenge. The Path to the Future of Energy. 2020. Available online: https://www2.deloitte.com/cn/ en/pages/energy-and-resources/articles/pr-the-2030-decarbonization-challenge.html (accessed on 9 October 2021).

117. UBS Bank Won't Fund New Offshore Arctic Oil, Gas Projects. 2020. Available online: https://www.pbs.org/newshour/economy/ ubs-bank-wont-fund-new-offshore-arctic-oil-gas-projects (accessed on 20 August 2021).

118. Mitrova, A.; Grushevenko, E.; Malov, A. Prospects for Russian Oil Production: Life Under Sanctions SEneC. 2018. Available online: https:/ / energy.skolkovo.ru/downloads/documents/SEneC/research04-ru.pdf (accessed on 12 July 2021).

119. Johan Sverdrup, the North Sea Giant, is on Stream. 2019. Available online: https://www.equinor.com/en/news/2019-10-johansverdrup.html (accessed on 30 May 2021).

120. Kozlova, D.; Pifarev, D. Digital Mining: Tuning for the Industry. 2018. Available online: https://vygon.consulting/upload/ iblock/d11/vygon_consulting_digital_upstream.pdf (accessed on 24 July 2021).

121. Tretyakov, N.; Cherepovitsyn, A.; Komendantova, N. Technology predictions for Arctic hydrocarbon development: Digitalization potential. In Technological Transformation: A New Role For Human, Machines And Management; Schaumburg, H., Korablev, V., Ungvári, L., Eds.; Springer International Publishing: Cham, Switzerland, 2021; pp. 241-251, ISBN 978-3-030-64429-1.

122. CSR in the Arctic-Way Forward. 2013. Available online: https://oaarchive.arctic-council.org/bitstream/handle/11374/1221 /Doc5-1_CSR_Website_layout.pdf?sequence=1\&isAllowed=y (accessed on 19 July 2021).

123. Oil and Gas Projects in the Arctic-Further Development If Possible. Our Assessments and Actions. 2021. Available online: https:/ / www.imemo.ru/files/File/ru/conf/2009/27052009/270509_prz_KNI.pdf (accessed on 22 July 2021).

124. Fetisov, V.; Pshenin, V.; Nagornov, D.; Lykov, Y.; Mohammadi, A.H. Evaluation of pollutant emissions into the atmosphere during the loading of hydrocarbons in marine oil tankers in the Arctic region. J. Mar. Sci. Eng. 2020, 8, 917. [CrossRef] 
125. Al-Qudah, A.A.; Al-Okaily, M.; Alqudah, H. The relationship between social entrepreneurship and sustainable development from economic growth perspective: 15 “RCEP” countries. J. Sustain. Financ. Invest. 2021, 1, 1-18. [CrossRef]

126. Xie, J.; Nozawa, W.; Yagi, M.; Fujii, H.; Managi, S. Do environmental, social, and governance activities improve corporate financial performance? Bus. Strategy Environ. 2019, 289, 286-300. [CrossRef]

127. Nasrallah, N.; El Khoury, R. Is corporate governance a good predictor of SMEs financial performance? Evidence from developing countries (the case of Lebanon). J. Sustain. Financ. Invest. 2021, 11, 1-31. [CrossRef]

128. Ferrero-Ferrero, I.; Fernández-Izquierdo, M.Á.; Muñoz-Torres, M.J. The effect of environmental, social and governance consistency on economic results. Sustainability 2016, 8, 1005. [CrossRef]

129. Rahi, A.F.; Akter, R.; Johansson, J. Do sustainability practices influence financial performance? Evidence from the Nordic financial industry. J. Account. Res. 2021, in press. [CrossRef]

130. Alsayegh, M.F.; Abdul Rahman, R.; Homayoun, S. Corporate economic, environmental, and social sustainability performance transformation through ESG disclosure. Sustainability 2020, 12, 3910. [CrossRef]

131. Buallay, A. Is sustainability reporting (ESG) associated with performance? Evidence from the European banking sector. Manag. Environ. Qual. 2019, 30, 98-115. [CrossRef]

132. Oncioiu, I.; Popescu, D.-M.; Aviana, A.E.; Serban, A.; Rotaru, F.; Petrescu, M.; Marin-Pantelescu, A. The role of environmental, social, and governance disclosure in financial transparency. Sustainability 2020, 12, 6757. [CrossRef]

133. Jonek-Kowalska, I.; Ponomarenko, T.V.; Marinina, O.A. Problems of interaction with stakeholders during implementation of long-term mining projects. J. Min. Inst. 2018, 232, 428-437. [CrossRef]

134. Global Sustainable Investment Review 2020. 2020. Available online: http://www.gsi-alliance.org/wp-content/uploads/2021/0 8/GSIR-20201.pdf (accessed on 19 September 2021).

135. Dickson, C. Working Together. What is Next for the Arctic? 2018. Available online: http:/ /awsassets.panda.org/downloads/ TheCircle0118_WEB.pdf (accessed on 16 August 2021).

136. Mastepanov, A.M. On the competitiveness of oil and gas projects of the Arctic shelf in conditions of low energy prices. Neftegaz. $R U$ 2017, 1, 20-30.

137. Kozmenko, S.; Savelyev, A.; Teslya, A. Impact of global and regional factors on dynamics of industrial development of hydrocarbons in the Arctic continental shelf and on investment attractiveness of energy projects. IOP Conf. Ser. Earth Environ. Sci. 2019, 302, 012124. [CrossRef]

138. Cherepovitcyn, A.E.; Romasheva, N.V.; Chvileva, T.A. Prospects for the exploration of hydrocarbon deposits in the Arctic based on socio-economic evaluation. Int. J. Civ. Eng. Technol. 2019, 13, 938-948. 